$11-1-2016$

\title{
Cash Flow News, Discount Rate News, and Momentum
}

Umut Celiker

u.celiker@csuohio.edu

Nuri Volkan Kayacetin

Raman Kumar

Gokhan Sonaer

Follow this and additional works at: https://engagedscholarship.csuohio.edu/bus_facpub

Part of the Finance and Financial Management Commons

How does access to this work benefit you? Let us know!

Publisher's Statement

NOTICE: this is the author's version of a work that was accepted for publication in the Journal of Banking and Finance. Changes resulting from the publishing process, such as peer review, editing, corrections, structural formatting, and other quality control mechanisms may not be reflected in this document. Changes may have been made to this work since it was submitted for publication. A definitive version was subsequently published in the Journal of Banking and Finance, 72, 11-01-2016, 10.1016/j.jbankfin.2016.07.016

\section{Recommended Citation}

Celiker, Umut; Kayacetin, Nuri Volkan; Kumar, Raman; and Sonaer, Gokhan, "Cash Flow News, Discount Rate News, and Momentum" (2016). Business Faculty Publications. 260.

https://engagedscholarship.csuohio.edu/bus_facpub/260

This Article is brought to you for free and open access by the Monte Ahuja College of Business at EngagedScholarship@CSU. It has been accepted for inclusion in Business Faculty Publications by an authorized administrator of EngagedScholarship@CSU. For more information, please contact library.es@csuohio.edu. 


\title{
Cash flow news, discount rate news, and momentum
}

\author{
Umut Celiker $^{\mathrm{a}, \mathrm{b}}$, Nuri Volkan Kayacetin ${ }^{\mathrm{b}}$, Raman Kumar ${ }^{\mathrm{a}, *}$, Gokhan Sonaer ${ }^{\mathrm{c}}$
}

\section{Introduction}

The profitability of the momentum strategy has become one of the most intriguing asset pricing phenomena since it was first documented in Jegadeesh and Titman (1993). ${ }^{1}$ Theoretical studies propose behavioral and rational explanations for momentum returns. $^{2}$ There is also extensive empirical literature on how momentum returns vary in the cross-section as well as in the time-series conditioned on market states. ${ }^{3}$ This paper focuses on the latter relation.

Extant empirical evidence suggests momentum profits critically depend on the state of the market. Cooper et al. (2004) show that the momentum strategy is profitable only in states when past market returns are non-negative. Antoniou et al. (2013) show that momentum is stronger when sentiment is optimistic and this effect is incremental to the effect of past market returns. These papers attribute the dependence of momentum on past market returns and investor sentiment to an increase in behavioral biases when the market performs well or sentiment is optimistic. ${ }^{4}$ Cooper et al. (2004) argue that overconfidence increases and risk aversion declines for the average investor following high market returns, effectively leading to overreaction and greater momentum profits. Antoniou et al. (2013) posit that investors with cognitive dissonance underreact to the news that contradicts investor sentiment. Consequently, bad (good) news diffuses slowly among loser (winner) stocks when aggregate investor sentiment is optimistic (pessimistic). They find that momentum strategy is profitable only under optimism, which is consistent with the notion of the greater difficulty of arbitraging overpriced loser stocks due to costly short selling.

In theory, the unexpected component of the market returns can be driven by two different sources of news: aggregate cash flow news and discount rate news. In this paper, we examine whether the nature of the news that drives past market returns has an 
effect on momentum profits. To this end, we decompose unexpected market returns in the portfolio formation period into components related to cash flow and discount rate news via the return decomposition methodology of Campbell and Vuolteenaho (2004). As noted in their paper, an important distinction between cash flow news and discount rate news is that, while cash flow news is thought to have a relatively permanent impact on prices, the impact of discount rate news is relatively transitory: a decline in asset values due to higher discount rates is at least partially compensated by higher expected returns in subsequent periods. In contrast, the future expected returns may remain unchanged when the value of the market portfolio falls as a result of bad news about future cash flows. Similarly, an increase in the value of market portfolio due to positive cash flow news may not be reversed subsequently, whereas an increase in the value of market portfolio due to discount rate news is offset by deteriorated prospects for future returns. Therefore, while shocks to wealth due to discount rate news can be interpreted as relatively short-term or transitory, shocks to wealth due to cash flow news are relatively more longterm and permanent. ${ }^{5}$ Based on these arguments, we conjecture that permanent cash flow shocks may have a greater impact on behavioral biases such as cognitive dissonance (Antoniou et al., 2013) in comparison to transitory discount rate shocks.

We follow Campbell (1991) and use the Campbell-Shiller (1988) return decomposition along with a vector autoregressive (VAR) approach to decompose unexpected market returns (RM) during the formation period into components due to cash flow news and discount rate news (NCF and NDR). ${ }^{6}$ We aggregate each of these components over rolling six-month periods and label a given month as an up-CF/DR state if the cumulative NCF /NDR in the prior six-month period is positive and as a down-CF/DR state if the cumulative NCF/NDR in the prior six-month period is negative.

We find that momentum is significantly higher following a series of positive aggregate cash flow news. The mean monthly return for the six-month formation/holding period momentum strategy is $1.28 \%$ in up-CF states, whereas it is only $0.29 \%$ in down$\mathrm{CF}$ states. The predictive ability of past cash flow news is robust to controlling for past market returns and sentiment. More strikingly, we find that momentum profits are still economically and statistically strong in up-CF states even when cumulative past market returns are negative (i.e., down markets based on Cooper et al., 2004 definition). Similarly, even when the investors are pessimistic, as per Antoniou et al. (2013) definition of pessimistic states based on the Conference Board sentiment data, we find that momentum is strong in up-CF states. We also find that the major driver of the higher momentum in up-CF states is the relatively higher persistence in the underperformance of losers. In downDR states, univariate sorts based on past discount rate news yield marginally significantly higher momentum profits, but these findings are dominated by past market returns or sentiment. We confirm these results in multivariate regressions.
We conduct a battery of robustness tests. We run out-of-sample tests which maintain a real time framework by employing a continuously updated (expanding window) VAR along with Jegadeesh and Titman (1993) calendar-time momentum strategy. We adjust for risk using both the Fama and French (1993) three-factor model and on size and book-to-market adjusted returns similar to that in Daniel et al. (1997). We further test the robustness of our results with value-weighted portfolio returns and in various subperiods. The positive relationship between past $C F$ and the momentum profits is robust to all of the above specifications.

Our analysis suggests that the conditioning role of past market returns and sentiment in the context of price momentum requires special attention with respect to what accounts for the variation in prices. Our findings are consistent with the predictions of the behavioral model in Hong and Stein (1999) and with Antoniou et al. (2013) who augment this model. Hong and Stein (1999) assume two types of traders, "newswatchers" and "momentum traders". In their framework, newswatchers trade based on private information that gradually diffuses among them, causing an initial underreaction. Momentum traders on the other hand, chase the trends in prices and cause overreaction in stock prices, which is eventually corrected. Antoniou et al. (2013) augment Hong and Stein (1999) model by introducing the notion of cognitive dissonance, which can cause greater underreaction of newswatchers to losers (winners) in optimistic (pessimistic) periods. Arbitraging the underreaction of losers is less likely than arbitraging the underreaction of winners due to costly short selling. Therefore, momentum differential between optimistic and pessimistic states is expected to be driven by the continuation of the underperformance of the losers in optimistic states. We contribute to this argument by hypothesizing that the positive permanent changes in wealth causes greater cognitive dissonance among newswatchers. Even in pessimistic states (when sentiment is low) behavioral biases such as cognitive dissonance of newswatchers may still be at play when there is positive cash flow news.

Our findings also complement the results of Cooper et al. (2004), who find that momentum is nonexistent following market declines. We show that momentum is profitable following positive cash flow news even in down markets based on past market returns. We argue that during down markets (past market returns are negative) investors pay greater attention to cash flow news as the shocks to wealth due to cash flow news are more permanent. Behavioral biases continue to exist after down markets when cash flows news indicates an up state.

There are also studies that examine whether momentum profits are procyclical. For example, Chordia and Shivakumar (2002) find that momentum profits exist only in expansionary periods and disappear after controlling for a set of macroeconomic variables that predict business cycles. ${ }^{7}$ Kim et al. (2014) provide further evidence for the procyclicality of momentum profits by documenting the difference in expected returns between winner and loser stocks across business cycles. In this paper, following Cooper et al. (2004) and Antoniou et al. (2013), we focus on the behavioral explanation for the relation between momentum and market states. However, in order to examine whether higher momentum returns following up-CF states is driven by the procyclicality of cash flow news and momentum returns, we repeat our main analysis by using cash flow and discount rate news orthogonalized with respect to the business cycle variables used in Chordia and Shivakumar (2002) and Kim et al. (2014). We find no evidence that the relationship between cash flow news and momentum returns is driven by the procyclicality of cash flow news. 
The remainder of the paper is organized as follows. Section 2 discusses the data and methodologies and present momentum profits in different cash flow and discount rate news. In Section 3, we present the momentum profits in market states determined by the use of past market returns and Conference Board (CB) sentiment measures. We conclude in Section 4.

\section{Cash flow and discount rate news}

Following Campbell (1991), we use the log-linear present value identities as in Campbell and Shiller (1988) and a vector autoregressive (VAR) model as in Campbell and Vuolteenaho (2004) to decompose market returns into cash flow news and discount rate news:

$r_{t+1}-E_{t} r_{t+1}=\left(E_{t+1}-E_{t}\right) \sum_{i=0}^{\infty} \rho^{i} \Delta d_{t+i+1}-\left(E_{t+1}-E_{t}\right) \sum_{i=1}^{\infty} \rho^{i} r_{t+i+1}$

where $r_{t+1}$ is a log market return from time $t$ to time $t+1, d_{t+1}$ is the log dividend paid at time $t+1, \Delta d_{t+1}$ represents the log change in dividends from time $t$ to time $t+1$, and $\rho$ is a parameter of linearization. ${ }^{8}$ In this model, cash flow news and discount rate news are defined as follows:

$N_{C F, t+1}=\left(E_{t+1}-E_{t}\right) \sum_{i=0}^{\infty} \rho^{i} \Delta d_{t+i+1}=$ news about future cash flows

$N_{D R, t+1}=\left(E_{t+1}-E_{t}\right) \sum_{i=1}^{\infty} \rho^{i} r_{t+i+1} \equiv$ news about future discount rates

To operationalize this decomposition, we assume a first-order VAR system of the form:

$z_{t+1}=a+B z_{t}+w_{t+1}$

where $z$ represents the vector of state variables, $a$ and $B$ are constants, and $w$ is the vector of shocks. Cash flow news and discount rate news can then be found as functions of the shocks:

$N_{C F, t+1}=\left(e 1^{\prime}+\lambda\right) w_{t+1}$.

$N_{D R, t+1}=\lambda w_{t+1}$

where $\lambda \equiv e 1^{\prime} \rho B(I-\rho B)^{-1}, I$ is an identity matrix, and $e 1$ is a vector with its first element equal to 1 and others equal to 0 .

Following Campbell and Vuolteenaho (2004), we include four state variables: (i) $r_{m}$ : $\log$ market return, measured as the $\log$ return on CRSP value weighted index, (ii) TY: term yield spread, measured as the percentage difference between the yield on the 10 -year US constant maturity bonds and the yield on short-term taxable notes. ${ }^{9}$ (iii) PE: $\log$ price earnings ratio from Shiller (2000), measured as the $\log$ of the price of the S\&P 500 index scaled with the 10-year trailing moving average of the aggregate earnings of the firms in the index, (iv) VS: small stock value spread, measured as the difference between the log of the book-to-market ratios of small value and small growth firms. The series is obtained from Professor Kenneth French's website.

Panels $A$ and $B$ of Table 1 respectively report the summary statistics of the VAR state variables and estimated cash flow news
Table 1

Descriptive statistics.

Panel A shows the descriptive statistics of the VAR state variables for the sample period December 1928-June 2013 covering 1015 monthly data points. $R m$ is the $\log$ return on the CRSP value-weighted index. $T Y$ is the term yield spread, measured as the yield difference between 10-year constant-maturity taxable bonds and short-term taxable notes. PE is the log ratio of the S\&P 500's price to the S\&P 500's 10-year moving average of earnings. VS is the value spread measured as the difference in the log book-to-market ratios of small value and small growth stocks. Panel B shows the properties of cash flow news (NCF) and discount rate news (NDR) estimated by the VAR model using the state variables in Panel A. Panel $\mathrm{C}$ shows the time-series average of the correlations between cumulative past market returns, news estimated by the VAR, and a sentiment proxy. p6NCF and P6NDR are the cumulative past six months cash flow news and discount rate news, respectively. p6rwret and p12vwret are the cumulative past 12 months value-weighted market returns. Sentiment is measured as the residual of the regression of Conference Board Sentiment Index on growth in industrial production, real growth in durable, nondurable and services consumption, growth in employment and an NBER recession indicator. For each formation period, month $t-1$, sentiment is calculated as the weighted average of past three months residual sentiment with weights 0.5 for month $t-1,0.33$ for month $t-2$ and 0.16 for month $t-3$.

\begin{tabular}{lcccccc}
\hline \multicolumn{7}{l}{ Panel A. Descriptive statistics of VAR state variables } \\
\hline Variable & Mean & Median & Std. dev. & \multicolumn{1}{l}{ Min } & Max & Autocorr. \\
\hline Rm & 0.004 & 0.009 & 0.054 & -0.344 & 0.322 & 0.113 \\
TY & 0.661 & 0.590 & 0.632 & -1.350 & 2.720 & 0.913 \\
PE & 2.905 & 2.921 & 0.365 & 1.501 & 3.891 & 0.992 \\
VS & 1.623 & 1.510 & 0.359 & 1.154 & 2.713 & 0.991 \\
\hline
\end{tabular}

Panel B. Cash flow and discount rate news of the market portfolio

\begin{tabular}{llrlll}
\hline & Mean & Median & Std. dev. & Min & Max \\
\hline CF news & 0 & 0.003 & 0.034 & -0.181 & 0.251 \\
DR news & 0 & -0.002 & 0.051 & -0.250 & 0.248 \\
Past 6 CF news & 0.0027 & 0.005 & 0.073 & -0.258 & 0.278 \\
Past 6 DR news & 0.0069 & -0.007 & 0.120 & -0.354 & 0.647 \\
\hline
\end{tabular}

Panel C. The cumulative CF, DR news, and market returns in different states

\begin{tabular}{llclcr}
\hline & p6vwret & p12vwret & p6ncf_fs & p6ndr_fs & Residsent \\
\hline p6vwret & 1.00 & 0.69 & 0.44 & -0.76 & -0.08 \\
p12vwret & 0.69 & 1.00 & 0.31 & -0.56 & -0.04 \\
p6ncf_fs & 0.44 & 0.31 & 1.00 & 0.14 & 0.07 \\
p6ndr_fs & -0.76 & -0.56 & 0.14 & 1.00 & -0.10 \\
Residsent & -0.08 & -0.04 & 0.07 & -0.10 & 1.00 \\
\hline
\end{tabular}

and discount rate news (NCF and NDR). Panel B shows that NDR has a standard deviation of $5.1 \%$ per month, 50\% larger than the $3.4 \%$ standard deviation of NCF. The same pattern exists when we cumulate the monthly news over the past six months. These are in line with the findings of Campbell (1991) and Campbell and Vuolteenaho (2004) that NDR plays a more important role in moving stock prices than NCF. Panel $C$ of Table 1 reports the correlations between past market returns (RM) and different types of news. While the correlation coefficient between NCF and RM is 0.44 , the correlation between NDR and RM is -0.76 . On the other hand, we find that the correlations with the residual sentiment are 0.07 for NCF and -0.10 for NDR.

\section{Hypothesis development and empirical evidence}

There are two different types of news that drive unexpected market returns: discount rate news and cash flow news. The term 'discount rate news (shock)' is synonymous with a change in future expected returns. While an increase in discount rates leads to a contemporaneous capital loss due to heavier discounting of expected future cash flows, investors are compensated at least partially by higher returns that are expected to accrue in future periods. By contrast, 'cash flow news (shock)' refers to a capital gain or loss that is brought about by changing expectations about 
future cash flows, which is permanent in the sense that it occurs in the absence of an offsetting shift in expected returns. This perspective is provided first by Campbell (1991), who argues that these two return components can be interpreted as the permanent and transitory components of returns, since returns generated by cash flow news are not subsequently reversed, whereas positive (negative) returns generated by discount rate news are offset by lower (higher) future returns. We hypothesize that permanent shocks to wealth may have a more pronounced effect on cognitive dissonance, thereby creating a greater underreaction to contradictory news in comparison to transitory wealth shocks. For example, when the market experiences positive aggregate cash flow news (up-CF state), investors would underreact to bad firm-specific news since such news conflicts with aggregate positive cash flows news. Furthermore, we argue that the underreaction to negative firm specific news in up-CF states would be greater than that to positive firm specific news in down-CF states because arbitraging away underreaction to bad news requires costly short-selling. Thus, positive cash flow news should lead to more pronounced behavioral biases and consequently to higher momentum portfolio returns, primarily due to the persistence in the underperformance of past losers.

\subsection{Momentum returns conditional on cash flow and discount rate news-full sample}

We start our analysis by computing the momentum returns in up and down states based on past cash flow and discount rate news over the period from January 1930 to December 2013. We employ a first-order VAR model as described in Section 2 including a constant, the log market return, term yield spread, log price-earnings ratio, and small stock value spread to obtain cash flow news (NCF) and discount rate news (NDR). We identify event months $(t)$ with non-negative cumulative NCF/NDR over the past 6 months ( $t-6$ to $t-1)$ as up-CF/DR states, with negative news over the past six months ( $t-6$ to $t-1)$ as down-CF/DR states.

We follow a similar methodology to that of Cooper et al. (2004) to compute momentum returns in these states in event time. For each month $(t)$ in our sample period, we sort all NYSE and AMEX stocks into deciles based on their past six-month ( $t-6$ to $t-1$ ) cumulative returns. We identify the bottom (top) decile port- folio, which is comprised of stocks with the lowest (highest) past cumulative six-month returns, as the loser (winner) portfolio. We compute the equal weighted average monthly returns for each of these decile portfolios for the following six months $(t+1$ to $t+6)$, skipping a month $(t)$ after the formation period. We then calculate the cumulative returns for these decile portfolios over the holding period ( $t+1$ to $t+6)$ forming time-series of raw cumulative returns over the six month holding period for each decile portfolio. For example, for the month of January $1960(t)$, the cumulative return over the holding period months is the sum of monthly raw returns from February, March, April, May, June, and July of $1960(t+1$ to $t+6$ ), and the end of formation period month is December 1959 $(t-1)$. We also form time-series of raw cumulative returns for the momentum portfolio, or WML, which is long in the winner portfolio and short in the loser portfolio. We convert cumulative returns to monthly returns by dividing by six. We then compute the time-series means of these returns separately during up and down states (based on state of month $t$ ) for each decile portfolio and the momentum portfolio. Following Cooper et al. (2004), we regress the time-series of momentum returns on an up state dummy variable and a down state dummy variable, with no intercept to test if the mean momentum returns are equal to zero (Momret $=a 1 \times$ UP Dummy $+a 2 \times$ DOWN Dummy). Also, in order to test for the difference in momentum returns between up and down states, we regress the time-series of momentum returns on an intercept and an up state dummy (Momret $=a+b \times U P$ Dummy). Using this approach, we are able to preserve the full time-series of observations, and reliably estimate the standard errors by taking into account any possible serial correlation.

Panel A of Table 2 presents the mean returns of the decile portfolios and WML in up- and down-CF states. The corresponding tstatistics, computed with a heteroscedasticity and auto-correlation consistent (HAC) estimate of the variance, are presented in parentheses. We set the number of lags equal to five, as the number of overlapping months for six-month formation - six-month holding period momentum strategy is five.

As seen in this panel, mean returns increase monotonically as we go from the loser portfolio to the winner portfolio in up-CF states and the mean return for WML is strongly significant $1.28 \%$ per month. In down-CF states, however, there is no obvious relation between past cumulative returns and holding period returns,

\section{Table 2}

Momentum returns conditional on cash flow and discount rate news.

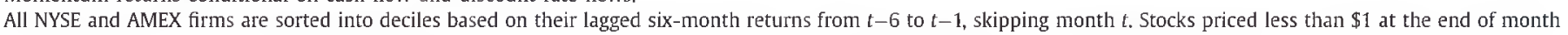

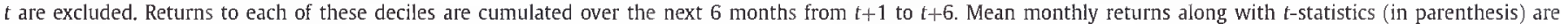

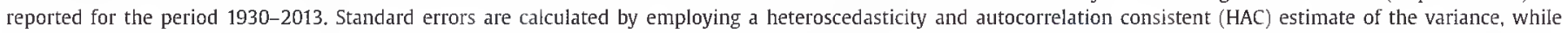

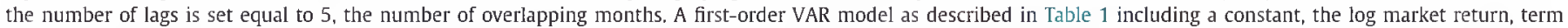

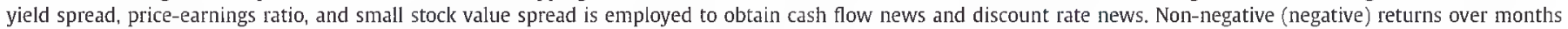
$t-6$ to $t-1$ define up (down) states. The number of observations for each state $(N)$ is also reported.

\begin{tabular}{|c|c|c|c|c|c|c|c|c|c|c|c|}
\hline \multicolumn{12}{|c|}{ Panel A. Cash flow states } \\
\hline & Loser & 2 & 3 & 4 & 5 & 6 & 7 & 8 & 9 & Winner & WML \\
\hline Up & $-0.20 \%$ & $0.23 \%$ & $0.44 \%$ & $0.53 \%$ & $0.60 \%$ & $0.66 \%$ & $0.76 \%$ & $0.83 \%$ & $0.94 \%$ & $1.08 \%$ & $1.28 \%$ \\
\hline$(N=536)$ & $(-0.84)$ & $(1.14)$ & $(2.30)$ & (2.84) & (3.25) & $(3.60)$ & $(4.14)$ & $(4.34)$ & $(4.63)$ & $(4.61)$ & (11.65) \\
\hline Down & $1.35 \%$ & $1.43 \%$ & $1.41 \%$ & $1.36 \%$ & $1.35 \%$ & $1.33 \%$ & $1.27 \%$ & $1.32 \%$ & $1.36 \%$ & $1.64 \%$ & $0.29 \%$ \\
\hline$(N=467)$ & (3.05) & (3.81) & $(4.22)$ & (4.39) & $(4.71)$ & $(4.89)$ & $(4.91)$ & $(5.29)$ & $(5.42)$ & (5.72) & $(1.10)$ \\
\hline Up-down & $-1.55 \%$ & $-1.20 \%$ & $-0.97 \%$ & $-0.83 \%$ & $-0.75 \%$ & $-0.67 \%$ & $-0.51 \%$ & $-0.49 \%$ & $-0.42 \%$ & $-0.56 \%$ & $1.00 \%$ \\
\hline & $(-3.38)$ & $(-3.10)$ & $(-2.78)$ & $(-2.59)$ & $(-2.48)$ & $(-2.32)$ & $(-1.84)$ & $(-1.79)$ & $(-1.52)$ & $(-1.77)$ & $(3.62)$ \\
\hline \multicolumn{12}{|c|}{ Panel B. Discount rate states } \\
\hline & Loser & 2 & 3 & 4 & 5 & 6 & 7 & 8 & 9 & Winner & W-L \\
\hline Up & $0.62 \%$ & $0.81 \%$ & $0.87 \%$ & $0.90 \%$ & $0.89 \%$ & $0.90 \%$ & $0.91 \%$ & $0.96 \%$ & $0.99 \%$ & $1.17 \%$ & $0.55 \%$ \\
\hline$(N=472)$ & $(1.59)$ & $(2.44)$ & $(2.96)$ & $(3.3)$ & $(3.53)$ & $(3.8)$ & $(4.09)$ & $(4.44)$ & $(4.66)$ & $(4,82)$ & $(2.19)$ \\
\hline Down & $0.43 \%$ & $0.77 \%$ & $0.91 \%$ & $0.93 \%$ & $0.99 \%$ & $1.03 \%$ & $1.08 \%$ & $1.15 \%$ & $1.27 \%$ & $1.50 \%$ & $1.06 \%$ \\
\hline$(N=531)$ & $(1.44)$ & $(3.12)$ & $(3.96)$ & $(4.24)$ & $(4.69)$ & $(4.87)$ & $(5.00)$ & $(5.27)$ & $(5.44)$ & $(5.52)$ & $(8.40)$ \\
\hline \multirow[t]{2}{*}{ Up-Down } & $0.19 \%$ & $0.04 \%$ & $-0.04 \%$ & $-0.03 \%$ & $-0.10 \%$ & $-0.13 \%$ & $-0.17 \%$ & $-0.20 \%$ & $-0.28 \%$ & $-0.33 \%$ & $-0.52 \%$ \\
\hline & $(0.42)$ & $(0.10)$ & $(-0.11)$ & $(-0.08)$ & $(-0.35)$ & $(-0.47)$ & $(-0.63)$ & $(-0.75)$ & $(-1.04)$ & $(-1.08)$ & $(-1.97)$ \\
\hline
\end{tabular}


Table 3

Momentum returns conditional on cash flow and discount rate news - sub-periods.

All NYSE and AMEX firms are sorted into deciles based on their lagged six-month returns from $t-6$ to $t-1$, skipping month $t$. Stocks priced less than $\$ 1$ at the end of month $t$ are excluded. Returns to each of these deciles are cumulated over the next 6 months from $t+1$ to $t+6$. Mean monthly returns along with t-statistics (in parenthesis) are reported for the winner, loser and momentum portfolios for the four sub-periods, 1930-1964, 1965-1989, 1990-1999, and 2000-2013. Standard errors are calculated by employing a heteroskedasticity and autocorrelation consistent (HAC) estimate of the variance, while the number of lags is set equal to 5 , the number of overlapping months. A first-order VAR model as described in Table 1 including a constant, the log market return, term yield spread, price-earnings ratio, and small stock value spread is employed to obtain cash flow news and discount rate news. Non-negative (negative) returns over months $t-6$ to $t-1$ define up (down) states. The number of observations for each state $(N$ ) is also reported.

\begin{tabular}{|c|c|c|c|c|c|c|c|}
\hline \multicolumn{8}{|c|}{ Panel A. Before $1965(N=422)$} \\
\hline & \multirow[b]{2}{*}{ All } & \multicolumn{3}{|c|}{ Cash flow states } & \multicolumn{3}{|c|}{ Discount rate states } \\
\hline & & Up & Down & Diff & Up & Down & Diff \\
\hline Loser & $\begin{array}{l}1.08 \% \\
(2.34)\end{array}$ & $\begin{array}{c}0.44 \% \\
(1.13)\end{array}$ & $\begin{array}{l}1.79 \% \\
(2.35)\end{array}$ & $\begin{array}{l}-1.35 \% \\
(-1.77)\end{array}$ & $\begin{array}{c}0.70 \% \\
(1.18)\end{array}$ & $\begin{array}{l}1.43 \% \\
(2.49)\end{array}$ & $\begin{array}{l}-0.73 \% \\
(-0.99)\end{array}$ \\
\hline Winner & $\begin{array}{c}1.58 \% \\
(4.37)\end{array}$ & $\begin{array}{c}1.33 \% \\
(3.22)\end{array}$ & $\begin{array}{l}1.87 \% \\
(3.91)\end{array}$ & $\begin{array}{l}-0.53 \% \\
(-1.03)\end{array}$ & $\begin{array}{r}1.12 \% \\
(3.22)\end{array}$ & $\begin{array}{c}2.03 \% \\
(3.85)\end{array}$ & $\begin{array}{l}-0.91 \% \\
(-1.7)\end{array}$ \\
\hline WML & $\begin{array}{r}0.51 \% \\
(2.49)\end{array}$ & $\begin{array}{c}0.90 \% \\
(6.14)\end{array}$ & $\begin{array}{l}0.08 \% \\
(0.2)\end{array}$ & $\begin{array}{c}0.82 \% \\
(1.99)\end{array}$ & $\begin{array}{c}0.41 \% \\
(1.19)\end{array}$ & $\begin{array}{c}0.60 \% \\
(3.04)\end{array}$ & $\begin{array}{l}-0.19 \% \\
(-0.49)\end{array}$ \\
\hline \multicolumn{8}{|c|}{ Panel B. Jegadeesh and Titman (1993) sample (1965-1989) (N=300) } \\
\hline Loser & $\begin{array}{l}-0.07 \% \\
(-0.16)\end{array}$ & $\begin{array}{l}-0.96 \% \\
(-2.18)\end{array}$ & $\begin{array}{c}1.01 \% \\
(1.65)\end{array}$ & $\begin{array}{l}-1.97 \% \\
(-2.87)\end{array}$ & $\begin{array}{c}0.11 \% \\
(0.19)\end{array}$ & $\begin{array}{l}-0.26 \% \\
(-0.6)\end{array}$ & $\begin{array}{c}0.38 \% \\
(0.55)\end{array}$ \\
\hline Winner & $\begin{array}{l}1.16 \% \\
(3.2)\end{array}$ & $\begin{array}{c}0.68 \% \\
(1.66)\end{array}$ & $\begin{array}{l}1.75 \% \\
(3.4)\end{array}$ & $\begin{array}{l}-1.07 \% \\
(-1.87)\end{array}$ & $\begin{array}{l}1.16 \% \\
(2.51)\end{array}$ & $\begin{array}{r}1.17 \% \\
(2.59)\end{array}$ & $\begin{array}{l}-0.02 \% \\
(-0.03)\end{array}$ \\
\hline WML & $\begin{array}{c}1.23 \% \\
(6.09)\end{array}$ & $\begin{array}{c}1.64 \% \\
(7.29)\end{array}$ & $\begin{array}{r}0.74 \% \\
(2.68)\end{array}$ & $\begin{array}{c}0.90 \% \\
(2.92)\end{array}$ & $\begin{array}{l}1.04 \% \\
(3.5)\end{array}$ & $\begin{array}{l}1.44 \% \\
(6.7)\end{array}$ & $\begin{array}{l}-0.40 \% \\
(-1.19)\end{array}$ \\
\hline \multicolumn{8}{|c|}{ Panel C. Jegadeesh and Titman (2001) sample $(1990-1999)(N=120)$} \\
\hline Loser & $\begin{array}{c}-0.21 \% \\
(-0.47)\end{array}$ & $\begin{array}{c}-0.42 \% \\
(-0.82)\end{array}$ & $\begin{array}{l}-0.02 \% \\
(-0.03)\end{array}$ & $\begin{array}{c}-0.40 \% \\
(-0.46)\end{array}$ & $\begin{array}{c}0.50 \% \\
(0.66)\end{array}$ & $\begin{array}{c}-0.47 \% \\
(-1.06)\end{array}$ & $\begin{array}{c}0.97 \% \\
(1.31)\end{array}$ \\
\hline Winner & $\begin{array}{c}1.44 \% \\
(4.27)\end{array}$ & $\begin{array}{c}1.72 \% \\
(3.69)\end{array}$ & $\begin{array}{r}1.19 \% \\
(2.76)\end{array}$ & $\begin{array}{c}0.52 \% \\
(0.87)\end{array}$ & $\begin{array}{c}1.97 \% \\
(3.92)\end{array}$ & $\begin{array}{c}1.25 \% \\
(3.42)\end{array}$ & $\begin{array}{c}0.72 \% \\
(1.39)\end{array}$ \\
\hline WML & $\begin{array}{l}1.65 \% \\
(5.8)\end{array}$ & $\begin{array}{r}2.14 \% \\
(8.37)\end{array}$ & $\begin{array}{c}1.21 \% \\
(2.95)\end{array}$ & $\begin{array}{c}0.93 \% \\
(2.20)\end{array}$ & $\begin{array}{c}1.47 \% \\
(3.08)\end{array}$ & $\begin{array}{c}1.72 \% \\
(5.32)\end{array}$ & $\begin{array}{l}-0.25 \% \\
(-0.47)\end{array}$ \\
\hline \multicolumn{8}{|c|}{ Panel D. 2000 s (Jan. 2000-May.2013) (N=161) } \\
\hline Loser & $\begin{array}{c}0.71 \% \\
(0.94)\end{array}$ & $\begin{array}{l}-0.27 \% \\
(-0.53)\end{array}$ & $\begin{array}{r}2.00 \% \\
(1.39)\end{array}$ & $\begin{array}{c}-2.26 \% \\
(-1.58)\end{array}$ & $\begin{array}{l}1.45 \% \\
(1.2)\end{array}$ & $\begin{array}{c}0.01 \% \\
(0.01)\end{array}$ & $\begin{array}{c}1.44 \% \\
(1.19)\end{array}$ \\
\hline Winner & $\begin{array}{c}0.96 \% \\
(1.96)\end{array}$ & $\begin{array}{c}0.80 \% \\
(1.75)\end{array}$ & $\begin{array}{r}1.17 \% \\
(1.42)\end{array}$ & $\begin{array}{l}-0.37 \% \\
(-0.44)\end{array}$ & $\begin{array}{c}0.98 \% \\
(1.56)\end{array}$ & $\begin{array}{c}0.93 \% \\
(1.69)\end{array}$ & $\begin{array}{c}0.05 \% \\
(0.07)\end{array}$ \\
\hline WML & $\begin{array}{c}0.25 \% \\
(0.46)\end{array}$ & $\begin{array}{c}1.06 \% \\
(4.45)\end{array}$ & $\begin{array}{l}-0.83 \% \\
(-0.73)\end{array}$ & $\begin{array}{c}1.90 \% \\
(2.30)\end{array}$ & $\begin{array}{l}-0.47 \% \\
(-0.47)\end{array}$ & $\begin{array}{c}0.93 \% \\
(3.39)\end{array}$ & $\begin{array}{c}-1.39 \% \\
(-1.48)\end{array}$ \\
\hline
\end{tabular}

and the mean momentum portfolio return is not significantly different from zero. We also compute the difference in returns for these portfolios in up- and down-CF states and document that the mean momentum portfolio return is significantly higher by $1.00 \%$ per month during up-CF states. ${ }^{10}$

We perform a similar analysis based on up- and down-DR states and present the results of this analysis in Panel B of Table 2. In this case, mean returns increase as we go from the loser decile to the winner decile in both up- and down-DR states. Although momentum profits are significant in both states, the mean return is marginally higher $(0.52 \%)$ in down-DR states. The difference between momentum returns across up and down states, however, is much smaller compared to that across up- and down-CF states. ${ }^{11}$
The results presented in this section suggest that momentum profits in up-CF states are significantly higher than that in down-CF states, and this difference in momentum profits is primarily driven by the continuation of the underperformance of losers in up-CF states. This finding is supportive of our contention that permanent increases in wealth accentuate cognitive dissonance. Therefore, investors underreact to conflicting bad firm-specific news in up-CF states, slowing the diffusion of such news for the loser stocks among investors. This is also consistent with the notion that arbitraging away underreaction to negative news through short selling is more costly than arbitraging away underreaction to positive news through buying. Our results also indicate that losers significantly underperform winners in both up-DR and down-DR states. Furthermore, the difference between returns of losers in up-DR and down-DR states is insignificant. This suggests that increases in wealth due to discount rate news (down-DR states) do not accentuate the cognitive dissonance among investors towards negative firm specific news as the effect of discount rate news on wealth is transitory.

\subsection{Sub-period analysis}

We also perform a sub-period analysis to examine whether the conditioning effect of past cash flow news on momentum returns is robust in different time periods. To this end, we divide our sample period into four subperiods, 1930-1964, 
Table 4

Momentum returns conditional on past market returns, cash flow news and discount rate news.

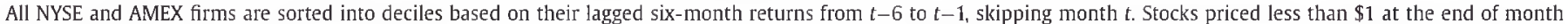

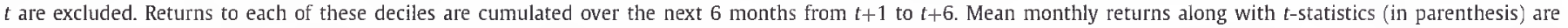

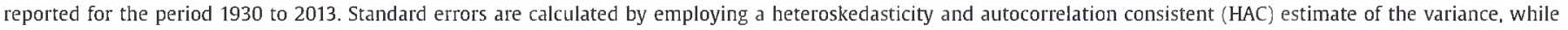

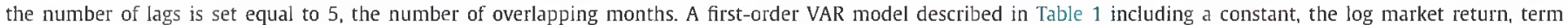

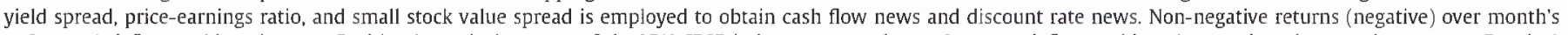

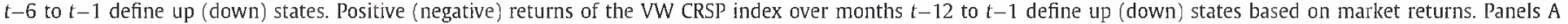
and $\mathrm{B}$ report the results for up and down states based on past market returns, respectively. The number of observations for each state ( $N$ ) is also reported.

\begin{tabular}{|c|c|c|c|c|c|c|c|c|c|c|c|}
\hline CF state & Loser & 2 & 3 & 4 & 5 & 6 & 7 & 8 & 9 & Winner & WML \\
\hline $\begin{array}{l}\text { Up } \\
(N=105) \\
\text { Down } \\
(N=169) \\
\text { Up-down }\end{array}$ & $\begin{array}{c}0.25 \% \\
(0.37) \\
2.65 \% \\
(2.59) \\
-2.40 \% \\
(-2.27)\end{array}$ & $\begin{array}{c}0.52 \% \\
(0.85) \\
2.31 \% \\
(2.53) \\
-1.79 \% \\
(-1.97)\end{array}$ & $\begin{array}{c}0.63 \% \\
(1.12) \\
2.02 \% \\
(2.49) \\
-1.39 \% \\
(-1.69)\end{array}$ & $\begin{array}{c}0.79 \% \\
(1.41) \\
1.90 \% \\
(2.48) \\
-1.11 \% \\
(-1.43)\end{array}$ & $\begin{array}{c}0.81 \% \\
(1.50) \\
1.71 \% \\
(2.44) \\
-0.91 \% \\
(-1.26)\end{array}$ & $\begin{array}{c}0.88 \% \\
(1.67) \\
1.65 \% \\
(2.43) \\
-0.77 \% \\
(-1.11)\end{array}$ & $\begin{array}{c}1.00 \% \\
(1.94) \\
1.58 \% \\
(2.50) \\
-0.59 \% \\
(-0.92)\end{array}$ & $\begin{array}{c}1.02 \% \\
(1.97) \\
1.50 \% \\
(2.49) \\
-0.48 \% \\
(-0.77)\end{array}$ & $\begin{array}{c}1.07 \% \\
(2.01) \\
1.47 \% \\
(2.49) \\
-0.40 \% \\
(-0.67)\end{array}$ & $\begin{array}{c}1.27 \% \\
(2.11) \\
1.73 \% \\
(2.66) \\
-0.47 \% \\
(-0.71)\end{array}$ & $\begin{array}{r}1.01 \% \\
(3.60) \\
-0.92 \% \\
(-1.54) \\
1.93 \% \\
(2.92)\end{array}$ \\
\hline DR state & Loser & 2 & 3 & 4 & 5 & 6 & 7 & 8 & 9 & Winner & WML \\
\hline $\begin{array}{l}\text { Up } \\
(N=206) \\
\text { Down } \\
(N=68) \\
\text { Up-down }\end{array}$ & $\begin{array}{c}1.45 \% \\
(1.89) \\
2.57 \% \\
(2.08) \\
-1.11 \% \\
(-0.82)\end{array}$ & $\begin{array}{c}1.41 \% \\
(2.11) \\
2.26 \% \\
(2.04) \\
-0.85 \% \\
(-0.71)\end{array}$ & $\begin{array}{c}1.29 \% \\
(2.17) \\
2.09 \% \\
(1.98) \\
-0.79 \% \\
(-0.71)\end{array}$ & $\begin{array}{c}1.28 \% \\
(2.29) \\
2.06 \% \\
(2.01) \\
-0.78 \% \\
(-0.73)\end{array}$ & $\begin{array}{c}1.16 \% \\
(2.24) \\
2.00 \% \\
(2.02) \\
-0.84 \% \\
(-0.81)\end{array}$ & $\begin{array}{c}1.12 \% \\
(2.32) \\
2.05 \% \\
(2.07) \\
-0.93 \% \\
(-0.9)\end{array}$ & $\begin{array}{c}1.06 \% \\
(2.36) \\
2.25 \% \\
(2.21) \\
-1.19 \% \\
(-1.14)\end{array}$ & $\begin{array}{c}1.05 \% \\
(2.48) \\
2.12 \% \\
(2.12) \\
-1.08 \% \\
(-1.04)\end{array}$ & $\begin{array}{c}0.98 \% \\
(2.43) \\
2.34 \% \\
(2.21) \\
-1.36 \% \\
(-1.25)\end{array}$ & $\begin{array}{c}1.21 \% \\
(2.70) \\
2.58 \% \\
(2.20) \\
-1.37 \% \\
(-1.16)\end{array}$ & $\begin{array}{r}-0.24 \% \\
(-0.47) \\
0.02 \% \\
(0.05) \\
-0.26 \% \\
(-0.48)\end{array}$ \\
\hline \multicolumn{12}{|c|}{ Panel B. Up states based on past 12 months VW market returns } \\
\hline CF state & Loser & 2 & 3 & 4 & 5 & 6 & 7 & 8 & 9 & Winner & WML \\
\hline $\begin{array}{l}\text { Up } \\
(N=431) \\
\text { Down } \\
(N=298) \\
\text { Up-down }\end{array}$ & $\begin{array}{c}-0.31 \% \\
(-1.29) \\
0.61 \% \\
(1.72) \\
-0.92 \% \\
(-2.43)\end{array}$ & $\begin{array}{c}0.16 \% \\
(0.82) \\
0.93 \% \\
(3.37) \\
-0.77 \% \\
(-2.51)\end{array}$ & $\begin{array}{c}0.40 \% \\
(2.09) \\
1.06 \% \\
(4.19) \\
-0.67 \% \\
(-2.34)\end{array}$ & $\begin{array}{c}0.46 \% \\
(2.55) \\
1.06 \% \\
(4.66) \\
-0.60 \% \\
(-2.29)\end{array}$ & $\begin{array}{c}0.55 \% \\
(3.01) \\
1.14 \% \\
(5.32) \\
-0.59 \% \\
(-2.38)\end{array}$ & $\begin{array}{r}0.61 \% \\
(3.29) \\
1.15 \% \\
(5.64) \\
-0.55 \% \\
(-2.25)\end{array}$ & $\begin{array}{r}0.71 \% \\
(3.79) \\
1.09 \% \\
(5.36) \\
-0.39 \% \\
(-1.61)\end{array}$ & $\begin{array}{c}0.79 \% \\
(4.05) \\
1.22 \% \\
(5.85) \\
-0.44 \% \\
(-1.75)\end{array}$ & $\begin{array}{c}0.91 \% \\
(4.34) \\
1.30 \% \\
(5.95) \\
-0.39 \% \\
(-1.48)\end{array}$ & $\begin{array}{c}1.04 \% \\
(4.29) \\
1.58 \% \\
(6.11) \\
-0.55 \% \\
(-1.77)\end{array}$ & $\begin{array}{r}1.35 \% \\
(11.62) \\
0.97 \% \\
(5.24) \\
0.38 \% \\
(2.02)\end{array}$ \\
\hline DR state & Loser & 2 & 3 & 4 & 5 & 6 & 7 & 8 & 9 & Winner & WML \\
\hline $\begin{array}{l}\text { Up } \\
(N=266) \\
\text { Down } \\
(N=463) \\
\text { Up-down }\end{array}$ & $\begin{array}{c}-0.03 \% \\
(-0.11) \\
0.12 \% \\
(0.43) \\
-0.15 \% \\
(-0.45)\end{array}$ & $\begin{array}{c}0.34 \% \\
(1.48) \\
0.56 \% \\
(2.47) \\
-0.21 \% \\
(-0.78)\end{array}$ & $\begin{array}{c}0.55 \% \\
(2.59) \\
0.74 \% \\
(3.57) \\
-0.19 \% \\
(-0.75)\end{array}$ & $\begin{array}{c}0.61 \% \\
(3.08) \\
0.76 \% \\
(3.93) \\
-0.15 \% \\
(-0.65)\end{array}$ & $\begin{array}{c}0.69 \% \\
(3.68) \\
0.85 \% \\
(4.48) \\
-0.16 \% \\
(-0.71)\end{array}$ & $\begin{array}{c}0.74 \% \\
(3.96) \\
0.88 \% \\
(4.7) \\
-0.15 \% \\
(-0.67)\end{array}$ & $\begin{array}{c}0.79 \% \\
(4.28) \\
0.91 \% \\
(4.75) \\
-0.11 \% \\
(-0.52)\end{array}$ & $\begin{array}{c}0.89 \% \\
(4.55) \\
1.01 \% \\
(5.14) \\
-0.12 \% \\
(-0.54)\end{array}$ & $\begin{array}{c}1.00 \% \\
(4.87) \\
1.11 \% \\
(5.31) \\
-0.11 \% \\
(-0.46)\end{array}$ & $\begin{array}{c}1.13 \% \\
(4.7) \\
1.34 \% \\
(5.40) \\
-0.21 \% \\
(-0.71)\end{array}$ & $\begin{array}{r}1.16 \% \\
(8.38) \\
1.22 \% \\
(8.94) \\
-0.06 \% \\
(-0.36)\end{array}$ \\
\hline
\end{tabular}

1965-1989, 1990-1999, and 2000-2013. The first sub-period is the period before Jegadeesh and Titman's (1993) sample period; the second is the Jegadeesh and Titman (1993) sample period; the third is the period which Jegadeesh and Titman (2001) use as an out-of-sample period; and the last is the period following the outof-sample period in Jegadeesh and Titman (2001). We perform the same analysis above for these sub-periods and report the results in Table 3.12

The mean return for WML is significantly positive during upCF states in all four subperiods. During down-CF states, however, the mean return for WML is significantly different from zero only in the second (1965-1989) and the third (1990-1999) subperiods. Importantly, the mean return for WML is significantly higher in up-CF states than in down-CF states in all sub-periods. This suggests that the conditioning effect of cash flows news on momentum returns is robust across different time periods. The results in Table 3 also show that momentum returns are slightly higher in down-DR states than in up-DR states. This difference, however, is not statistically significant in any of the four sub-periods considered.

\subsection{Momentum conditional on past market returns and cash flow and discount rate news}

Cooper et al. (2004) report that momentum strategy is profitable only following up-market states, periods with positive past cumulative market returns. They argue that behavioral biases increase after high market returns, which leads to overreaction and consequently to higher momentum profits. We report in Section 2 a positive (negative) correlation between the states based on market returns and those based on cash flow (discount rate) news.

To ensure that the results presented in the previous sections are not driven by the effect of market returns on the profitability of momentum strategy, we need to control for this effect. To this end, we first identify the up and down states based on past cumulative market returns, where the months with positive (negative) cumulative returns of the value weighted CRSP index over months the past months, $t-12$ to $t-1$, are defined as up market (down market) state. We then identify up and down states based on cash flow and discount rate news separately as in Section 3.1 during up-market and down market states. Finally, we compute the mean holding period returns of the momentum decile portfolios and WML as described in Section 3.1.

Panel A of Table 4 presents these mean returns for the up and down states based on cash flow news and discount rate news 
during down markets. Even during down markets based on past market returns, there is a strong positive relation between holding period returns and past cumulative returns in up-CF states. Furthermore, the mean return for WML is $1.01 \%$, which is economically and statistically (1\% level) significant. During down-CF states, however, the mean return for WML is negative, but insignificant. The difference between the mean holding period returns for WML in up and down states based on cash flow news during down markets is $1.93 \%$, significant at the $1 \%$ level. We repeat the same analysis for up- and down-DR states during down markets and find that the momentum strategy does not generate returns significantly different from zero in either discount rate state during down markets.

In Panel B of Table 4, we report the results for the up markets based on past 12 months of value-weighted market returns. During up markets, mean momentum portfolio return is significantly positive in both up- and down-CF states, but it is significantly higher during up-CF states. In contrast, there is no significant difference between the mean momentum portfolio returns in up- and downDR states.

Overall, our findings suggest that momentum portfolio returns are significantly higher during up-CF states even after controlling for up and down markets based on past market returns. Moreover, momentum portfolio is profitable during the up-CF states even when these periods coincide with down markets. Conversely, the effect of the discount rate news on the momentum portfolio returns is no longer evident after controlling for past market returns.

\subsection{Momentum returns conditional on sentiment, cash flow news and discount rate news}

Antoniou et al. (2013) argue that news diffuses slowly if it contradicts with the investor sentiment due to cognitive dissonance in investors. They contend that due to slow diffusion of bad news during periods of high sentiment losers become overpriced. Consistent with this argument, they document that momentum portfolio generates significantly positive returns only during periods of investor optimism. In this section, we address this argument by examining whether past cash flow and discount rate news can predict momentum returns after controlling for the investor sentiment.

We first compute the investor sentiment for each month from April 1967 to December 2010, when Conference Board (CB) sentiment data is available. More specifically, following Antoniou et al. (2013), for each month $t$, we calculate sentiment as the weighted average of past three month's residual sentiment with weights 0.5 for month $t-1,0.33$ for month $t-2$ and 0.17 for month $t-3$. We then split our sample period into 10 investor sentiment states based on the three-month rolling average sentiment time series. We compute the mean returns to the loser, winner, and momentum portfolios (WML) for each of these 10 investor sentiment levels. The mean returns for these portfolios are computed as discussed in Section 3.1. Panel A of Table 5 presents these mean returns and the corresponding t-statistics for each of the sentiment states. WML is not profitable during the bottom two sentiment states. However, during the remaining eight sentiment states WML generates positive and significant returns.

We next classify the bottom two states (remaining states) as the pessimistic (optimistic) periods. ${ }^{13}$ We then identify up and down states based on cash flow news and discount rate news separately as described in Section 3.1 during the pessimistic and optimistic periods. Panel B of Table 5 presents the mean returns to the decile portfolios and WML constructed as described in Section 3.1 for the up and down states separately based on cash flow news and discount rate news during pessimistic periods. Even during these pessimistic periods, there is a strong positive relation between past cumulative returns and holding period returns when cash flow news indicates an up state. In addition, the mean monthly return for WML is $1.25 \%$, which is statistically and economically significant. In contrast, when cash flow news indicates a down state momentum portfolio is not profitable. The difference between momentum returns in up- and down-CF states is also significant. On the other hand, past discount rate news has no effect on momentum returns during pessimistic periods. Momentum portfolio is not profitable in both up- and down-DR states during pessimistic periods.

Panel $C$ of Table 5 presents the results for optimistic periods. Although the momentum portfolio is profitable in both up- and down-CF states during optimistic periods, the momentum portfolio generates significantly higher returns $(0.62 \%$ monthly) in up-CF states. Conversely, similar to the evidence reported for pessimistic periods discount rate news does not affect the profitability of the momentum portfolio during optimistic periods.

Overall, our results suggest that past cash flows news predict future momentum returns even after controlling for investor sentiment. The striking finding is that the momentum strategy is profitable even during pessimistic periods if cash flow news indicates an up state. However, the conditioning effect of past discount rate news on momentum returns is subsumed by investor sentiment. These findings suggest that cognitive dissonance is at play even in pessimistic sentiment periods when cash flow news is positive. This may be because investors are paying close attention to the cash flow news.

\subsection{Alternative model specifications}

We acknowledge that the results of Section 3.1 are based on a particular VAR model which is used to decompose unexpected market returns during the formation period into components due to cash flow news and discount rate news. In this section, we examine the sensitivity of these results to changes in the model specification. To this end, following Chen and Zhao (2009) we employ alternative model specifications that use various combinations of predictive variables including 1-year PE ratio, dividend yield, bookto-market ratio, BM spread, market variance, and equity share in addition to the four factors we use in our initial tests. 1-year PE ratio is defined as the log one-year smoothed S\&P 500 price-earnings ratio. Dividend yield is the dividend-price ratio of the market portfolio, book-to-market is the book-to-market ratio of the Dow Jones Industrial average as in Pontiff and Schall (1998). BM spread is the book-to-market ratio of value stocks minus that of growth stocks, market variance is the sum of squared daily returns of S\&P 500 . Equity share is the share of equity issues in total new issues as in Baker and Wurgler (2000).

Panel A of Table 6 presents the predictive variables that are used in alternative model specifications to estimate the DR news and the CF news. Chen and Zhao (2009) suggest that, as the 10year PE ratio is highly persistent, it becomes the dominant factor in the main model of Campbell and Vuolteenaho (2004) which uses excess return, term spread, and value spread in addition to the $10-$ year $\mathrm{PE}$ ratio as the predictive variables. Therefore, we replace the 10 -year PE by the less persistent 1 -year PE ratio in model 1 . In models 2 and 3, the 10 -year PE ratio is replaced by the dividend yield and the book-to-market ratio, respectively. These variables are used alternatively with 10 -year PE ratio as expected return proxies in various studies (e.g., Pontiff and Shall, 1998; Lewellen, 1999). In model 4, the 10 -year PE ratio is replaced by the BM 
Table 5

Momentum returns conditional on sentiment, cash flow news and discount rate news.

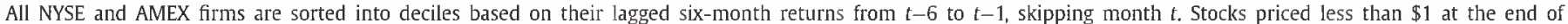

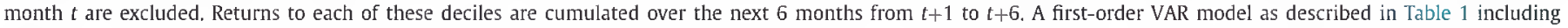

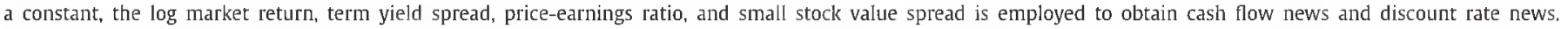

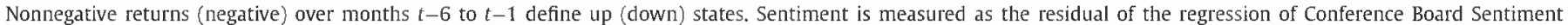

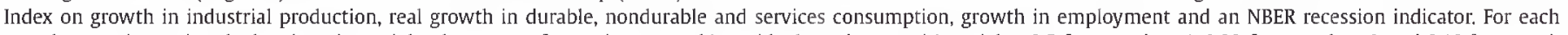
month $t$, sentiment is calculated as the weighted average of past three month's residual sentiment with weights 0.5 for month $t-1,0.33$ for month $t-2$ and 0.16 for month t-3. Panel A reports the equal-weighted returns of loser, winner and momentum portfolios (WML) for each of the sentiment deciles. Panel B reports the results for up

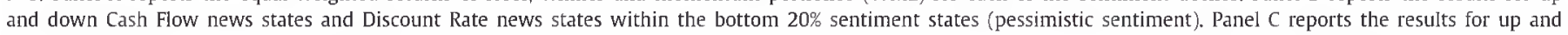
down Cash Flow news states and Discount Rate news states within the top 80\% sentiment states (optimistic sentiment). Standard errors are calculated by employing a

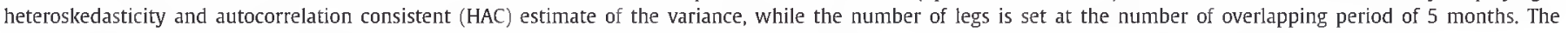
sample period is from April 1967 to December 2010 where CB sentiment data is available. The number of observations for each state ( $N$ ) is also reported.

\begin{tabular}{|c|c|c|c|c|c|c|c|c|c|c|c|}
\hline \multicolumn{12}{|c|}{ Panel A. Momentum returns and sentiment } \\
\hline \multicolumn{12}{|c|}{ Residual conference board sentiment } \\
\hline & Low & 2 & 3 & 4 & 5 & 6 & & 7 & 8 & 9 & High \\
\hline Loser & $\begin{array}{r}3.13 \% \\
(2.36)\end{array}$ & $\begin{array}{l}1.92 \% \\
(2.16)\end{array}$ & $\begin{array}{l}0.27 \% \\
(0.45)\end{array}$ & $\begin{array}{l}-0.58 \% \\
(-0.89)\end{array}$ & $\begin{array}{l}-0.21 \% \\
(-0.49)\end{array}$ & \multicolumn{2}{|c|}{$\begin{array}{c}-0.47 \% \\
(-0.82)\end{array}$} & $\begin{array}{l}-1.58 \% \\
(-2.47)\end{array}$ & $\begin{array}{l}-0.56 \% \\
(-0.81)\end{array}$ & $\begin{array}{l}-0.82 \% \\
(-1.41)\end{array}$ & $\begin{array}{l}-1.51 \% \\
(-2.18)\end{array}$ \\
\hline \multirow{2}{*}{ Winner } & $2.37 \%$ & $1.66 \%$ & $1.32 \%$ & $0.68 \%$ & \multirow{2}{*}{$\begin{array}{r}0.91 \% \\
(1.73)\end{array}$} & & $0.39 \%$ & $1.01 \%$ & $0.85 \%$ & $0.78 \%$ \\
\hline & $(5.28)$ & $(2.91)$ & $(1.54)$ & $(1.08)$ & & \multicolumn{2}{|c|}{$(1.87)$} & $(0,93)$ & $(2,37)$ & $(1.56)$ & $(0,9)$ \\
\hline \multirow[t]{2}{*}{ WML } & $-0.75 \%$ & $-0.26 \%$ & $1.05 \%$ & $1.26 \%$ & \multirow{2}{*}{$\begin{array}{r}1.11 \% \\
(3.86)\end{array}$} & \multirow{2}{*}{\multicolumn{2}{|c|}{$\begin{array}{l}1.29 \% \\
(5.11)\end{array}$}} & $1.96 \%$ & $1.58 \%$ & $1.67 \%$ & $2.29 \%$ \\
\hline & $(-0.59)$ & $(-0.46)$ & $(2.44)$ & $(4.16)$ & & & & $(5.93)$ & (4.96) & $(4.89)$ & $(5.76)$ \\
\hline \multicolumn{12}{|c|}{ Panel B. Pessimistic sentiment $(N=105)$} \\
\hline CF state & Loser & 2 & 3 & 4 & 5 & 6 & 7 & 8 & 9 & Winner & WML \\
\hline $\mathrm{Up}(N=48)$ & $\begin{array}{c}-0.04 \% \\
(-0.06)\end{array}$ & $\begin{array}{l}0.53 \% \\
(1.1)\end{array}$ & $\begin{array}{c}0.72 \% \\
(1.75)\end{array}$ & $\begin{array}{c}0.74 \% \\
(1.92)\end{array}$ & $\begin{array}{c}0.77 \% \\
(2.09)\end{array}$ & $\begin{array}{c}0.81 \% \\
(2.28)\end{array}$ & $\begin{array}{l}0.82 \% \\
(2.1)\end{array}$ & $\begin{array}{c}0.98 \% \\
(2.49)\end{array}$ & $\begin{array}{c}1.03 \% \\
(2.29)\end{array}$ & $\begin{array}{c}1.21 \% \\
(2.05)\end{array}$ & $\begin{array}{r}1.25 \% \\
(4.76)\end{array}$ \\
\hline Down $(N=57)$ & $\begin{array}{c}4.69 \% \\
(3.75)\end{array}$ & $\begin{array}{c}3.86 \% \\
(4.96)\end{array}$ & $\begin{array}{l}3.40 \% \\
(5.42)\end{array}$ & $\begin{array}{r}3.15 \% \\
(5.71)\end{array}$ & $\begin{array}{c}2.81 \% \\
(6.36)\end{array}$ & $\begin{array}{c}2.69 \% \\
(6.72)\end{array}$ & $\begin{array}{l}2.48 \% \\
(6.41)\end{array}$ & $\begin{array}{c}2.51 \% \\
(6.51)\end{array}$ & $\begin{array}{l}2.55 \% \\
(6.57)\end{array}$ & $\begin{array}{c}2.70 \% \\
(5.55)\end{array}$ & $\begin{array}{l}-1.99 \% \\
(-1.65)\end{array}$ \\
\hline Up-down & $\begin{array}{l}-4.72 \% \\
(-3.42)\end{array}$ & $\begin{array}{l}-3.33 \% \\
(-3.65)\end{array}$ & $\begin{array}{l}-2.69 \% \\
(-3.64)\end{array}$ & $\begin{array}{l}-2.41 \% \\
(-3.70)\end{array}$ & $\begin{array}{l}-2.04 \% \\
(-3.72)\end{array}$ & $\begin{array}{l}-1.88 \% \\
(-3.81)\end{array}$ & $\begin{array}{l}-1.67 \% \\
(-3.39)\end{array}$ & $\begin{array}{l}-1.54 \% \\
(-3.11)\end{array}$ & $\begin{array}{l}-1.51 \% \\
(-2.83)\end{array}$ & $\begin{array}{l}-1.48 \% \\
(-2.12)\end{array}$ & $\begin{array}{r}3.24 \% \\
(2.67)\end{array}$ \\
\hline DR state & Loser & 2 & 3 & 4 & 5 & 6 & 7 & 8 & 9 & Winner & WML \\
\hline $\mathrm{Up}(N=40)$ & $\begin{array}{r}4.17 \% \\
(2.37)\end{array}$ & $\begin{array}{l}3.30 \% \\
(2.85)\end{array}$ & $\begin{array}{c}2.99 \% \\
(3.14)\end{array}$ & $\begin{array}{c}2.74 \% \\
(3.36)\end{array}$ & $\begin{array}{c}2.33 \% \\
(3.54)\end{array}$ & $\begin{array}{c}2.12 \% \\
(3.47)\end{array}$ & $\begin{array}{c}2.02 \% \\
(3.61)\end{array}$ & $\begin{array}{r}1.97 \% \\
(3.75)\end{array}$ & $\begin{array}{c}1.90 \% \\
(3.63)\end{array}$ & $\begin{array}{l}2.15 \% \\
(3.3)\end{array}$ & $\begin{array}{l}-2.02 \% \\
(-1.12)\end{array}$ \\
\hline Down $(N=65)$ & $1.52 \%$ & $1.74 \%$ & $1.67 \%$ & $1.62 \%$ & $1.60 \%$ & $1.66 \%$ & $1.54 \%$ & $1.71 \%$ & $1.82 \%$ & $1.94 \%$ & $0.42 \%$ \\
\hline Up-down & $\begin{array}{r}(2.48) \\
2.65 \% \\
(1.48)\end{array}$ & $\begin{array}{r}(3.94) \\
1.56 \% \\
(1.29)\end{array}$ & $\begin{array}{c}(4.49) \\
1.32 \% \\
(1.31)\end{array}$ & $\begin{array}{r}(4.43) \\
1.11 \% \\
(1.28)\end{array}$ & $\begin{array}{c}(4.51) \\
0.72 \% \\
(0.99)\end{array}$ & $\begin{array}{c}(4.75) \\
0.45 \% \\
(0.66)\end{array}$ & $\begin{array}{c}(4.14) \\
0.48 \% \\
(0.72)\end{array}$ & $\begin{array}{c}(4.5) \\
0.27 \% \\
(0.42)\end{array}$ & $\begin{array}{c}(4.47) \\
0.08 \% \\
(0.12)\end{array}$ & $\begin{array}{c}(3.8) \\
0.22 \% \\
(0.26)\end{array}$ & $\begin{array}{r}(1.43) \\
-2.44 \% \\
(-1.37)\end{array}$ \\
\hline \multicolumn{12}{|c|}{ Panel C. Optimistic sentiment $(\mathrm{N}=419)$} \\
\hline \multirow{2}{*}{$\begin{array}{l}\text { CF state } \\
\text { Up }(N=228)\end{array}$} & Loser & 2 & 3 & 4 & 5 & 6 & 7 & 8 & 9 & Winner & WML \\
\hline & $\begin{array}{l}-1.00 \% \\
(-2.95)\end{array}$ & $\begin{array}{l}-0.36 \% \\
(-1.2)\end{array}$ & $\begin{array}{l}-0.03 \% \\
(-0.09)\end{array}$ & $\begin{array}{r}0.13 \% \\
(0.49)\end{array}$ & $\begin{array}{c}0.23 \% \\
(0.91)\end{array}$ & $\begin{array}{c}0.30 \% \\
(1.22)\end{array}$ & $\begin{array}{c}0.44 \% \\
(1.86)\end{array}$ & $\begin{array}{c}0.52 \% \\
(2.11)\end{array}$ & $\begin{array}{c}0.67 \% \\
(2.61)\end{array}$ & $\begin{array}{c}0.81 \% \\
(2.7)\end{array}$ & $\begin{array}{r}1.81 \% \\
(10.28)\end{array}$ \\
\hline Down $(N=191)$ & $\begin{array}{l}-0.30 \% \\
(-0.63)\end{array}$ & $\begin{array}{c}0.31 \% \\
(0.74)\end{array}$ & $\begin{array}{c}0.54 \% \\
(1.37)\end{array}$ & $\begin{array}{c}0.63 \% \\
(1.76)\end{array}$ & $\begin{array}{l}0.72 \% \\
(2.17)\end{array}$ & $\begin{array}{c}0.76 \% \\
(2.41)\end{array}$ & $\begin{array}{c}0.73 \% \\
(2.39)\end{array}$ & $\begin{array}{c}0.75 \% \\
(2.36)\end{array}$ & $\begin{array}{c}0.74 \% \\
(2.13)\end{array}$ & $\begin{array}{c}0.89 \% \\
(2.08)\end{array}$ & $\begin{array}{r}1.19 \% \\
(5.52)\end{array}$ \\
\hline Up-down & $\begin{array}{l}-0.70 \% \\
(-1.26)\end{array}$ & $\begin{array}{l}-0.67 \% \\
(-1.38)\end{array}$ & $\begin{array}{l}-0.56 \% \\
(-1.25)\end{array}$ & $\begin{array}{l}-0.50 \% \\
(-1.2)\end{array}$ & $\begin{array}{l}-0.50 \% \\
(-1.27)\end{array}$ & $\begin{array}{l}-0.46 \% \\
(-1.24)\end{array}$ & $\begin{array}{l}-0.28 \% \\
(-0.78)\end{array}$ & $\begin{array}{l}-0.23 \% \\
(-0.62)\end{array}$ & $\begin{array}{l}-0.07 \% \\
(-0.19)\end{array}$ & $\begin{array}{l}-0.08 \% \\
(-0.16)\end{array}$ & $\begin{array}{r}0.62 \% \\
(2.48)\end{array}$ \\
\hline DR state & Loser & 2 & 3 & 4 & 5 & 6 & 7 & 8 & 9 & Winner & WML \\
\hline $\mathrm{Up}(N=201)$ & $\begin{array}{c}-0.44 \% \\
(-0.98)\end{array}$ & $\begin{array}{c}0.07 \% \\
(0.17)\end{array}$ & $\begin{array}{c}0.30 \% \\
(0.79)\end{array}$ & $\begin{array}{c}0.47 \% \\
(1.35)\end{array}$ & $\begin{array}{c}0.50 \% \\
(1.53)\end{array}$ & $\begin{array}{c}0.61 \% \\
(1.94)\end{array}$ & $\begin{array}{c}0.65 \% \\
(2.17)\end{array}$ & $\begin{array}{c}0.74 \% \\
(2.45)\end{array}$ & $\begin{array}{c}0.81 \% \\
(2.53)\end{array}$ & $\begin{array}{c}0.89 \% \\
(2.35)\end{array}$ & $\begin{array}{r}1.33 \% \\
(6.25)\end{array}$ \\
\hline Down $(N=218)$ & $\begin{array}{c}-0.90 \% \\
(-2.96)\end{array}$ & $\begin{array}{r}-0.16 \% \\
(-0.63)\end{array}$ & $\begin{array}{l}0.17 \% \\
(0.7)\end{array}$ & $\begin{array}{c}0.25 \% \\
(1.14)\end{array}$ & $\begin{array}{l}0.41 \% \\
(1.93)\end{array}$ & $\begin{array}{c}0.42 \% \\
(2.03)\end{array}$ & $\begin{array}{c}0.50 \% \\
(2.48)\end{array}$ & $\begin{array}{r}0.51 \% \\
(2.38)\end{array}$ & $\begin{array}{c}0.61 \% \\
(2.54)\end{array}$ & $\begin{array}{c}0.81 \% \\
(2.73)\end{array}$ & $\begin{array}{r}1.71 \% \\
(9.71)\end{array}$ \\
\hline Up-down & $\begin{array}{c}0.47 \% \\
(1.00)\end{array}$ & $\begin{array}{c}0.23 \% \\
(0.58)\end{array}$ & $\begin{array}{r}0.13 \% \\
(0.34)\end{array}$ & $\begin{array}{c}0.22 \% \\
(0.62)\end{array}$ & $\begin{array}{r}0.10 \% \\
(0.29)\end{array}$ & $\begin{array}{l}0.19 \% \\
(0.6)\end{array}$ & $\begin{array}{r}0.15 \% \\
(0.49)\end{array}$ & $\begin{array}{c}0.24 \% \\
(0.76)\end{array}$ & $\begin{array}{c}0.21 \% \\
(0.63)\end{array}$ & $\begin{array}{c}0.09 \% \\
(0.21)\end{array}$ & $\begin{array}{r}-0.38 \% \\
(-1.53)\end{array}$ \\
\hline
\end{tabular}

spread. Liu and Zhang (2008) provide evidence that BM spread can pick up the counter-cyclicality of the expected return better than the value spread. In addition, Chen and Zhao (2009) argue that including this variable in the VAR model improves the predictive power, and hence it is a good proxy for expected return. In model 5, we also include equity share variable. Baker and Wurgler (2000) argue that equity share is a strong predictor of market returns. In model 6 , in addition to the three predictive variables used in the main model (excess return, term spread, and value spread), we include 1-year PE ratio, book-to-market ratio, market variance, and equity share as the predictive variables as in Model 7 in Table 2 of Chen and Zhao (2009).

We repeat the same analysis performed in Section 3.1 for these six alternative model specifications, which are used to decompose unexpected market returns (RM) during the formation period into components due to cash flow news and discount rate news. ${ }^{14}$ As in Section 3.1 we identify event months $(t)$ with non-negative cumulative NCF/NDR over the past six months ( $t-6$ to $t-1$ ) as up-CF/DR states, and with negative news over the past six months as down$\mathrm{CF} / \mathrm{DR}$ states for each of these six model specifications. We then compute the mean returns for the loser, winner and the momentum portfolio (WML), separately for the up and down states for 
Table 6

Momentum returns conditional on cash flow and discount rate news-alternative model specifications.

Six alternative first-order VAR models including a constant, the log market return, term yield spread, small stock value spread and various combinations of predictive variables including 1-year PE ratio, dividend yield, book-to-market ratio, BM spread, market variance, and equity share are employed to obtain cash flow news and discount rate news. Panel A presents the predictive variables that are used in these six alternative model specifications. Non-negative returns (negative) over months $t-6$ to $t-1$ define up (down) states. All NYSE and AMEX firms are sorted into deciles based on their lagged six-month returns from $t-6$ to $t-1$, skipping month $t$. Stocks priced less than $\$ 1$ at the end of month $t$ are excluded. Returns to bottom (loser), top (winner) deciles and the momentum portfolio (WML) that buys winner portfolio and sells loser portfolio are cumulated over the next 6 months from $t+1$ to $t+6$. In Panel $B$ and $C$, mean monthly returns along with $t$-statistics (in parenthesis) are reported for the period 1930-2013 for the up and down CF and DR states, respectively, for these six alternative model specifications. Standard errors are calculated by employing a heteroskedasticity and autocorrelation consistent (HAC) estimate of the variance, while the number of lags is set equal to 5 , the number of overlapping months. The number of observations for each state $(N)$ is also reported.

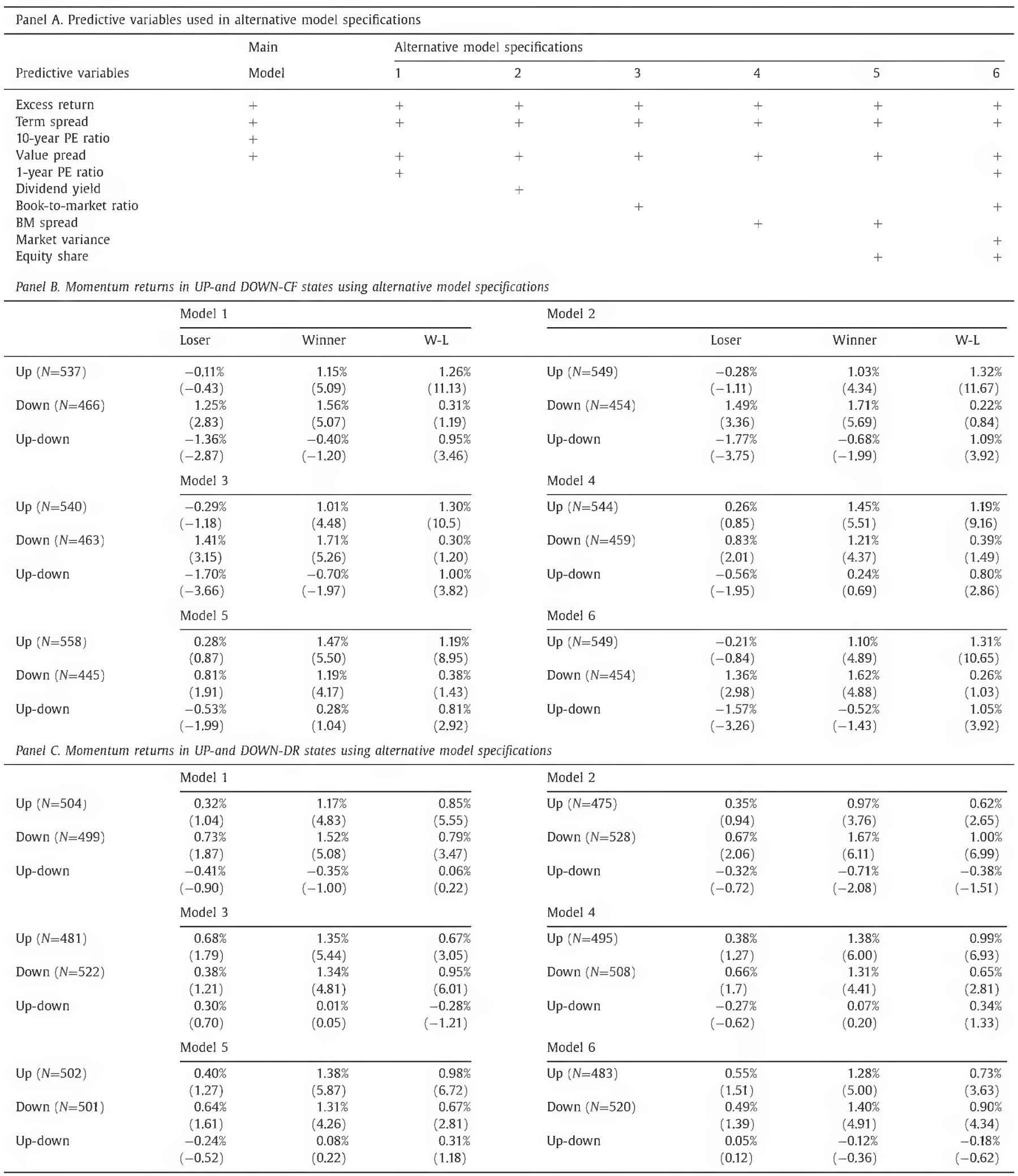


these alternative model specifications. Panel B of Table 6 presents these mean returns and the corresponding t-statistics (in parenthesis) computed with a heteroskedasticity and auto-correlation consistent (HAC) estimate of the variance for up- and down-CF states. The results for the alternative model specifications are similar to the main specification in our Section 3.1. Momentum portfolio returns are significantly positive during up-CF news and not significantly different from zero during down-CF states. In addition, the difference between momentum portfolio returns during up- and down-CF states is positive and significant for all alternative model specifications. The findings for the up- and down-DR states, reported in Panel $C$, are also similar to those for the main model specification. Therefore, we conclude that our results are not sensitive to alternative model specifications that are employed to decompose unexpected market returns during the formation period into cash flow and discount rate news components.

\subsection{Risk-adjustments}

In this section, we address the possibility that the higher momentum portfolio returns in up-CF states is driven by higher loadings on risk factors. Following Cooper et al. (2004) and Antoniou et al. (2013), we form a time-series of the raw momentum returns corresponding to the each event month of the holding period. We run time-series regressions of raw portfolio returns in excess of risk free rate on the standard set of risk factors used in extant empirical studies to estimate the factor loadings for each portfolio and for each holding period month. We then use these factor loadings to estimate the CAPM and Fama-French (1993) risk-adjusted profits as follows:

$r_{k t}^{a d j}=r_{k t}-\sum_{i} \hat{\beta}_{i k} f_{i t}$

where $r_{k t}$ is the raw return for the portfolio in holding period month $k$, for $k=1,2, \ldots, 6$, in calendar month $t, f_{i t}$ is the realization of factor $i$ in calendar month $t$, and $\hat{\beta}_{i k}$ is the estimated loading of the raw return of the portfolio on $f_{i k}$ for holding period month $k$. As risk factors, we use the excess return of the value-weighted market index over the 1-month T-bill return as the factor for the CAPM adjustment, and the return differential between small and big companies (SMB) and high and low book-to-market companies (HML) as the additional factors for the Fama-French (1993) threefactor (FF3) model. Finally, the monthly CAPM-adjusted and FF3 adjusted returns are cumulated over the holding period for each event month.

Table 7 presents the mean monthly abnormal returns along with robust $t$-statistics. In Panel A, the CAPM and FF3 excess return differences in momentum returns between up- and down-CF states are $0.86 \%(t=3.65)$ and $0.71 \%(t=3.22)$, respectively. Furthermore, the higher momentum portfolio return in up-CF states is entirely driven by the underperformance of losers. The losers in up-CF states underperform by $0.96 \%(t=4.04)$ and $0.60 \%(t=3.62)$ based on the CAPM and FF3 models, respectively. ${ }^{15}$ Conversely, there is no significant difference in momentum portfolio return between up- and down-DR states. Panels B and C of Table 7 present these mean abnormal returns for the up- and down-CF/DR states during down markets and pessimistic states, respectively. The patterns of momentum portfolio returns are in line with the previous findings based on raw returns in our previous tables. Thus, we conclude that the higher momentum returns in up-CF states cannot be explained by the risk premiums implied by standard asset pricing models such as CAPM and Fama and French (1993).

\subsection{Multivariate time series regressions using continuous measures}

We examine the relation between momentum and past cash flow and discount rate news, past market returns and investor sentiment as continuous variables or as dummy variables in a multivariate regression framework. The purpose is to examine whether the predictive role of past cash flow news is robust to the inclusion of other state variables. To this end, we run a time-series regression of momentum profits on lagged cash flow news, discount rate news, and dummy variables for down states and pessimistic sentiment states in the following model:

Momret $=a+b \times X+e$,

where $X$ may include, in different specifications in Table 8 , past cumulative cash flow news, past discount rate news, past market return, residual sentiment, dummy variable for down market states based on past market returns, dummy variable for pessimistic states based on residual sentiment, and interactions of dummy variables with cash flow news and discount rate news. Down Market Dummy takes the value of $1(0)$ if the past 12 months market return is negative (non-negative). Similarly, Pessimistic Sentiment Dummy takes the value of $1(0)$ if the sentiment is within the bottom $20 \%$ of the sentiment values. The variables other than dummy variables are measured in the same manner as in our portfolio analysis methodology.

Table 8 confirms the finding that past aggregate cash flow news positively predicts the momentum returns. In univariate regressions, the slope coefficient on past cash flow news is 0.64 , which is statistically significant at the $1 \%$ level. When we control for market returns, sentiment, and discount rate news, past aggregate cash flow news is still able to significantly predict momentum at the $1 \%$ level in Model 5.

To be consistent with our portfolio analysis, we use dummy variables for down market states and pessimistic states to measure any differential effect of cash flow news in different states of the market. In models (6)-(9), we include these dummy variables and their interactions with $\mathrm{CF} / \mathrm{DR}$ news. In line with the evidence from our portfolio analysis, the results from these tests confirm that past cash flow news positively predicts momentum profits in both down and up market states and the effect of cash flow news is stronger in down markets and pessimistic states. The differential effect is statistically significant at the $5 \%$ level. Past discount rate news, on the other hand, is not statistically significant at the conventional levels in either down markets or pessimistic states.

\subsection{Long horizon performance of momentum strategies}

In this section, we examine the long horizon pattern of momentum profits conditioned on cash flow news during the five years after portfolio formation. According to Hong and Stein (1999), the second type of investors in their model, namely "momentum traders" make their investment decisions based on the past price changes. The initial underreaction by "newswatchers" (the first investor type in the model) due to cognitive dissonance and gradual diffusion of news may increase the interest of momentum traders. As momentum traders pay attention only to price trends, some later momentum traders may cause an overreaction in stock prices. Hong and Stein (1999) further argue that the overreaction of momentum traders may decline with their risk-aversion. As Cooper et al. (2004) argue, the level of risk-aversion may decline following increases in wealth, which coincides with periods of positive market returns.

Existing empirical evidence provides support for the overreaction explanation. Jegadeesh and Titman (1993, 2001) show that momentum profits reverse in the period following the initial holding year, suggesting a mispricing 


\section{Table 7}

Risk-adjusted returns.

This table presents the risk-adjusted returns of losers, winners, and momentum portfolios caiculated from CAPM and Fama-French(1993). All NYSE and AMEX firms are allocated into deciles based on their lagged six-month returns from $t-6$ to $t-1$, skipping month $t$. Stocks priced less than $\$ 1$ at the end of month $t$ are excluded. A timeseries of returns for each portfolio and holding period month is formed and regressed on excess market return(according to the CAPM) and excess market return, the SMB and HML factors (according to the FF(1993) three-factor model) to obtain loadings on risk factors. The loadings and realizations of factors are used to estimate the excess returns of portfolios. All market states based on cash flow news, discount rate news, market returns and sentiment are defined as in previous tables. Standard errors are calculated by employing a heteroscedasticity and autocorrelation consistent (HAC) estimate of the variance, while the number of legs is set at the number of overlapping period of 5 months. Panel A reports the excess returns ( $t$-statistics) for univariate definition of states based on cash flow and discount rate news. Panel B reports the excess returns ( $t$-statistics) for bivariate sorts based on cash flow, discount rate news and market returns. Panel $\mathrm{C}$ reports the excess returns ( $t$-statistics) for bi-variate sorts based on cash flow, discount rate news and Conference Board Sentiment measure.

\begin{tabular}{|c|c|c|c|c|c|c|c|c|c|c|c|c|c|}
\hline \multicolumn{14}{|c|}{ Panel A. Alphas of Table 2} \\
\hline \multirow[b]{2}{*}{ CF state } & & \multicolumn{6}{|l|}{ CAPM } & & \multicolumn{5}{|c|}{ Fama-French (1993) } \\
\hline & & \multicolumn{2}{|l|}{ Loser } & \multicolumn{2}{|c|}{ Winner } & \multicolumn{2}{|c|}{ W-L } & & Loser & \multicolumn{2}{|r|}{ Winner } & \multicolumn{2}{|r|}{ W-L } \\
\hline Up & & \multicolumn{2}{|l|}{$\begin{array}{c}-0.93 \% \\
(-6.88)\end{array}$} & \multicolumn{2}{|c|}{$0.57 \%$} & \multicolumn{2}{|c|}{$1.50 \%$} & & $-1.10 \%$ & \multicolumn{2}{|r|}{$0.55 \%$} & \multicolumn{2}{|r|}{$\begin{array}{r}1.65 \% \\
(11.55)\end{array}$} \\
\hline \multicolumn{2}{|l|}{ Down } & \multicolumn{2}{|l|}{$\begin{array}{c}0.03 \% \\
(014)\end{array}$} & & $.68 \%$ & & $\begin{array}{l}.65 \% \\
98\end{array}$ & & $\begin{array}{l}-0.51 \% \\
(-3.43)\end{array}$ & & $\begin{array}{c}0.44 \% \\
(4.59)\end{array}$ & \multicolumn{2}{|r|}{$\begin{array}{r}(11.55) \\
0.94 \% \\
(4.88)\end{array}$} \\
\hline \multicolumn{2}{|l|}{ Up-down } & \multicolumn{2}{|l|}{$\begin{array}{c}-0.96 \% \\
(-4.04)\end{array}$} & $\begin{array}{l}-0 \\
(-0\end{array}$ & $\begin{array}{l}.11 \% \\
.66)\end{array}$ & & $86 \%$ & & $\begin{array}{l}-0.60 \% \\
(-3.62)\end{array}$ & & $\begin{array}{r}0.11 \% \\
(1.00)\end{array}$ & & $\begin{array}{c}0.71 \% \\
(3.22)\end{array}$ \\
\hline DR state & & Loser & & Winner & & W-1 & & & Loser & & Winner & & W-L \\
\hline Up & & $\begin{array}{l}-0.21 \% \\
(-1.04)\end{array}$ & & & $\begin{array}{l}.62 \% \\
.05)\end{array}$ & & $\begin{array}{l}.83 \% \\
81)\end{array}$ & & $\begin{array}{l}-0.69 \% \\
(-4.38)\end{array}$ & & $\begin{array}{c}0.40 \% \\
(4.37)\end{array}$ & & $\begin{array}{r}1.09 \% \\
(5.23)\end{array}$ \\
\hline Down & & $\begin{array}{l}-0.73 \% \\
(-4.36)\end{array}$ & & & $\begin{array}{l}.62 \% \\
.94)\end{array}$ & & $\begin{array}{l}.35 \% \\
.53)\end{array}$ & & $\begin{array}{l}-0.95 \% \\
(-9.95)\end{array}$ & & $\begin{array}{c}0.58 \% \\
(6.32)\end{array}$ & & $\begin{array}{c}1.53 \% \\
(11.40)\end{array}$ \\
\hline Up-down & & $\begin{array}{r}0.51 \% \\
(1.90)\end{array}$ & & $\begin{array}{l}-0 \\
-0\end{array}$ & $\begin{array}{l}.01 \% \\
.05)\end{array}$ & -0 & $\begin{array}{l}.52 \% \\
.89)\end{array}$ & & $\begin{array}{c}0.26 \% \\
(1.53)\end{array}$ & & $\begin{array}{c}-0.18 \% \\
(-1.51)\end{array}$ & & $\begin{array}{l}-0.44 \% \\
(-1.82)\end{array}$ \\
\hline Panel B. Al & phas of Tab & le 5 & & & & & & & & & & & \\
\hline Panel B.1. I & Down mark & thates & & & & & Panel B.2. & UP Market & states & & & & \\
\hline & CAPM & & & Fama-Fren & $\operatorname{ch}(1993)$ & & & CAPM & & & Fama-Fren & $\operatorname{ch}(1993)$ & \\
\hline CF state & Loser & Winner & W-L & Loser & Winner & W-L & CF state & Loser & Winner & W-L & Loser & Winner & W-L \\
\hline Up & $\begin{array}{c}-0.21 \% \\
(-0.62) \\
(5.56)\end{array}$ & $\begin{array}{c}1.05 \% \\
(4.28) \\
(11.54)\end{array}$ & $\begin{array}{c}1.26 \% \\
(3.71)\end{array}$ & $\begin{array}{c}-0.96 \% \\
(-3.16)\end{array}$ & $\begin{array}{c}0.68 \% \\
(4.12)\end{array}$ & $\begin{array}{c}1.64 \% \\
(4.30)\end{array}$ & Up & $\begin{array}{c}-1.11 \% \\
(-7.92)\end{array}$ & $\begin{array}{c}0.45 \% \\
(3.02)\end{array}$ & $\begin{array}{r}1.56 \% \\
(12.58)\end{array}$ & $\begin{array}{r}-1.15 \% \\
(-12.07)\end{array}$ & $0.52 \%$ & $1.67 \%$ \\
\hline Down & $\begin{array}{r}1.15 \% \\
(2.77)\end{array}$ & $\begin{array}{c}0.77 \% \\
(2.97)\end{array}$ & $\begin{array}{l}-0.39 \% \\
(-0.81)\end{array}$ & $\begin{array}{r}0.14 \% \\
(0.42)\end{array}$ & $\begin{array}{l}0.28 \% \\
(1.45)\end{array}$ & $\begin{array}{r}0.14 \% \\
(0.32)\end{array}$ & Down & $\begin{array}{l}-0.60 \% \\
(-2.78)\end{array}$ & $\begin{array}{c}0.63 \% \\
(4.02)\end{array}$ & $\begin{array}{c}1.23 \% \\
(7.75)\end{array}$ & $\begin{array}{c}-0.86 \% \\
(-8.31)\end{array}$ & $\begin{array}{r}0.51 \% \\
(5.36)\end{array}$ & $\begin{array}{r}1.37 \% \\
(10.82)\end{array}$ \\
\hline Up-down & $\begin{array}{c}-1.36 \% \\
(-2.82)\end{array}$ & $\begin{array}{c}0.29 \% \\
(0.94)\end{array}$ & $\begin{array}{c}1.65 \% \\
(2.99)\end{array}$ & $\begin{array}{l}-1.10 \% \\
(-2.70)\end{array}$ & $\begin{array}{c}0.40 \% \\
(1.77)\end{array}$ & $\begin{array}{r}1.50 \% \\
(2.79)\end{array}$ & Up-down & $\begin{array}{c}-0.50 \% \\
(-2.38)\end{array}$ & $\begin{array}{r}-0.17 \% \\
(-0.96)\end{array}$ & $\begin{array}{l}0.33 \% \\
(2.26)\end{array}$ & $\begin{array}{c}-0.29 \% \\
(-2.20)\end{array}$ & $\begin{array}{c}0.01 \% \\
(0.08)\end{array}$ & $\begin{array}{r}0.30 \% \\
(2.04)\end{array}$ \\
\hline DR state & Loser & Winner & W-L & Loser & Winner & W-L & DR state & Loser & Winner & W-L & Loser & Winner & W-L \\
\hline Up & $\begin{array}{c}0.58 \% \\
(1.53)\end{array}$ & $\begin{array}{c}0.72 \% \\
(3.58)\end{array}$ & $\begin{array}{r}0.14 \% \\
(0.31)\end{array}$ & $\begin{array}{l}-0.26 \% \\
(-0.81)\end{array}$ & $\begin{array}{c}0.32 \% \\
(1.89)\end{array}$ & $\begin{array}{c}0.58 \% \\
(1.38)\end{array}$ & Up & $\begin{array}{l}-0.83 \% \\
(-4.84)\end{array}$ & $\begin{array}{c}0.54 \% \\
(3.78)\end{array}$ & $\begin{array}{c}1.36 \% \\
(10.18)\end{array}$ & $\begin{array}{r}-1.02 \% \\
(-10.25)\end{array}$ & $\begin{array}{c}0.47 \% \\
(5.21)\end{array}$ & $\begin{array}{c}1.48 \% \\
(9.98)\end{array}$ \\
\hline Down & $\begin{array}{c}0.77 \% \\
(1.72)\end{array}$ & $\begin{array}{c}1.35 \% \\
(2.98)\end{array}$ & $\begin{array}{c}0.58 \% \\
(1.68)\end{array}$ & $\begin{array}{l}-0.34 \% \\
(-1.01)\end{array}$ & $\begin{array}{c}0.79 \% \\
(3.45)\end{array}$ & $\begin{array}{r}1.14 \% \\
(2.30)\end{array}$ & Down & $\begin{array}{l}-0.94 \% \\
(-5.59)\end{array}$ & $\begin{array}{l}0.52 \% \\
(3.16)\end{array}$ & $\begin{array}{r}1.46 \% \\
(10.97)\end{array}$ & $\begin{array}{c}-1.04 \% \\
(-10.98)\end{array}$ & $\begin{array}{c}0.55 \% \\
(5.62)\end{array}$ & $\begin{array}{r}1.59 \% \\
(12.01)\end{array}$ \\
\hline Up-down & $\begin{array}{r}-0.19 \% \\
(-0.35)\end{array}$ & $\begin{array}{c}-0.63 \% \\
(-1.38)\end{array}$ & $\begin{array}{c}-0.45 \% \\
(-0.84)\end{array}$ & $\begin{array}{c}0.08 \% \\
(0.18)\end{array}$ & $\begin{array}{c}-0.48 \% \\
(-1.84)\end{array}$ & $\begin{array}{c}-0.56 \% \\
(-0.90)\end{array}$ & Up-Down & $\begin{array}{r}0.12 \% \\
(0.53)\end{array}$ & $\begin{array}{c}0.02 \% \\
(0.09)\end{array}$ & $\begin{array}{r}-0.10 \% \\
(-0.60)\end{array}$ & $\begin{array}{c}0.02 \% \\
(0.19)\end{array}$ & $\begin{array}{l}-0.08 \% \\
(-0.71)\end{array}$ & $\begin{array}{r}-0.11 \% \\
(-0.63)\end{array}$ \\
\hline Panel C. Al & phas of Tab & le 6 & & & & & & & & & & & \\
\hline Panel C.1. I & Pessimistic & tates & & & & & Panel B.2. & Optimistic s & states & & & & \\
\hline & CAPM & & & Fama-Fren & $\operatorname{ch}(1993)$ & & & CAPM & & & Fama-Fren & ch(1993) & \\
\hline CF state & Loser & Winner & W-L & Loser & Winner & W-L & CF state & Loser & Winner & W-L & Loser & Winner & W-L \\
\hline Up & $\begin{array}{c}-0.88 \% \\
(-2.94)\end{array}$ & $\begin{array}{c}0.59 \% \\
(1.65)\end{array}$ & $\begin{array}{c}1.47 \% \\
(5.01)\end{array}$ & $\begin{array}{c}-1.43 \% \\
(-7.68)\end{array}$ & $\begin{array}{c}0.38 \% \\
(1.31)\end{array}$ & $\begin{array}{c}1.81 \% \\
(4.91)\end{array}$ & Up & $\begin{array}{c}-1.35 \% \\
(-5.13)\end{array}$ & $\begin{array}{c}0.66 \% \\
(2.88)\end{array}$ & $\begin{array}{c}2.01 \% \\
(9.97)\end{array}$ & $\begin{array}{l}-1.49 \% \\
(-8.18)\end{array}$ & $\begin{array}{c}0.69 \% \\
(5.19)\end{array}$ & $\begin{array}{r}2.17 \% \\
(10.24)\end{array}$ \\
\hline Down & $\begin{array}{c}1.62 \% \\
(2.30)\end{array}$ & $\begin{array}{c}0.65 \% \\
(1.34)\end{array}$ & $\begin{array}{l}-0.98 \% \\
(-1.06)\end{array}$ & $\begin{array}{c}0.59 \% \\
(0.86)\end{array}$ & $\begin{array}{r}0.14 \% \\
(0.36)\end{array}$ & $\begin{array}{l}-0.46 \% \\
(-0.49)\end{array}$ & Down & $\begin{array}{l}-0.84 \% \\
(-3.19)\end{array}$ & $\begin{array}{c}0.53 \% \\
(2.55)\end{array}$ & $\begin{array}{l}1.38 \% \\
(6.63)\end{array}$ & $\begin{array}{l}-1.09 \% \\
(-6.47)\end{array}$ & $\begin{array}{c}0.44 \% \\
(3.23)\end{array}$ & $\begin{array}{c}1.54 \% \\
(8.06)\end{array}$ \\
\hline Up-down & $\begin{array}{c}-2.50 \% \\
(-3.42)\end{array}$ & $\begin{array}{l}-0.05 \% \\
(-0.09)\end{array}$ & $\begin{array}{c}2.44 \% \\
(2.64)\end{array}$ & $\begin{array}{l}-2.02 \% \\
(-2.92)\end{array}$ & $\begin{array}{c}0.24 \% \\
(0.54)\end{array}$ & $\begin{array}{c}2.27 \% \\
(2.74)\end{array}$ & Up-down & $\begin{array}{l}-0.51 \% \\
(-2.16)\end{array}$ & $\begin{array}{r}0.13 \% \\
(0.52)\end{array}$ & $\begin{array}{l}0.64 \% \\
(2.50)\end{array}$ & $\begin{array}{c}-0.39 \% \\
(-1.78)\end{array}$ & $\begin{array}{l}0.24 \% \\
(1.50)\end{array}$ & $\begin{array}{c}0.64 \% \\
(2.57)\end{array}$ \\
\hline DR state & Loser & Winner & W-L & Loser & Winner & W-L & DR state & Loser & Winner & W-L & Loser & Winner & W-L \\
\hline Up & $\begin{array}{c}1.73 \% \\
(1.69)\end{array}$ & $\begin{array}{c}0.71 \% \\
(1.34)\end{array}$ & $\begin{array}{c}-1.02 \% \\
(-0.69)\end{array}$ & $\begin{array}{c}0.60 \% \\
(0.56)\end{array}$ & $\begin{array}{c}0.07 \% \\
(0.14)\end{array}$ & $\begin{array}{c}-0.52 \% \\
(-0.34)\end{array}$ & Up & $\begin{array}{c}-0.71 \% \\
(-2.62)\end{array}$ & $\begin{array}{c}0.81 \% \\
(4.34)\end{array}$ & $\begin{array}{c}1.52 \% \\
(6.43)\end{array}$ & $\begin{array}{c}-1.34 \% \\
(-6.26)\end{array}$ & $\begin{array}{c}0.55 \% \\
(4.12)\end{array}$ & $\begin{array}{c}1.89 \% \\
(7.64)\end{array}$ \\
\hline Down & $\begin{array}{c}-0.29 \% \\
(-0.80)\end{array}$ & $\begin{array}{c}0.57 \% \\
(1.63)\end{array}$ & $\begin{array}{c}0.85 \% \\
(3.05)\end{array}$ & $\begin{array}{l}-0.90 \% \\
(-5.45)\end{array}$ & $\begin{array}{c}0.35 \% \\
(1.45)\end{array}$ & $\begin{array}{c}1.26 \% \\
(5.73)\end{array}$ & Down & $\begin{array}{c}-1.50 \% \\
(-5.74)\end{array}$ & $\begin{array}{r}0.41 \% \\
(1.53)\end{array}$ & $\begin{array}{c}1.91 \% \\
(10.88)\end{array}$ & $\begin{array}{l}-1.28 \% \\
(-8.14)\end{array}$ & $\begin{array}{c}0.60 \% \\
(4.03)\end{array}$ & $\begin{array}{r}1.87 \% \\
(10.44)\end{array}$ \\
\hline Up-down & $\begin{array}{c}2.01 \% \\
(1.90)\end{array}$ & $\begin{array}{r}0.14 \% \\
(0.24)\end{array}$ & $\begin{array}{c}-1.87 \% \\
(-1.25)\end{array}$ & $\begin{array}{c}1.50 \% \\
(1.43)\end{array}$ & $\begin{array}{l}-0.28 \% \\
(-0.50)\end{array}$ & $\begin{array}{l}-1.78 \% \\
(-1.16)\end{array}$ & Up-down & $\begin{array}{c}0.79 \% \\
(2.29)\end{array}$ & $\begin{array}{c}0.39 \% \\
(1.32)\end{array}$ & $\begin{array}{c}-0.40 \% \\
(-1.48)\end{array}$ & $\begin{array}{l}-0.07 \% \\
(-0.27)\end{array}$ & $\begin{array}{l}-0.05 \% \\
(-0.29)\end{array}$ & $\begin{array}{c}0.02 \% \\
(0.05)\end{array}$ \\
\hline
\end{tabular}


Table 8

Momentum returns - multivariate analysis using continuous measures.

All NYSE and AMEX firms are sorted into deciles based on their lagged six-month returns from $t-6$ to $t-1$, skipping month $t$. Stocks priced less than $\$ 1$ at the end of month $t$ are excluded. Returns to each of these deciles are cumulated over the next 6 months from $t+1$ to $t+6$. For each month $t$ the six month cumulative returns to

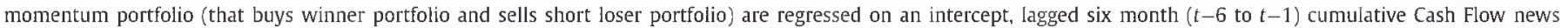

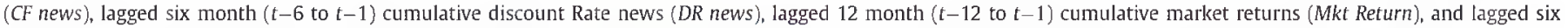

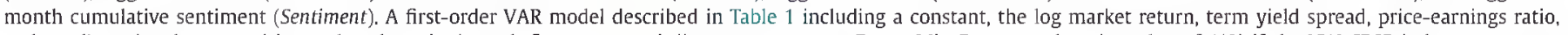
and small stock value spread is employed to obtain cash flow news and discount rate news. Down Mkt Dummy takes the value of $1(0)$ if the VW CRSP index return over months $t-12$ to $t-1$ is negative(nonnegative). For each month $t$, sentiment is calculated as the weighted average of past three month's residual sentiment with weights 0.5

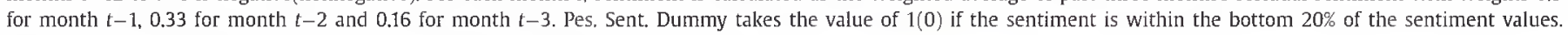
The heteroscedasticity and autocorrelation adjusted $t$-statistics are in parentheses.

\begin{tabular}{|c|c|c|c|c|c|c|c|c|c|}
\hline & 1 & 2 & 3 & 4 & 5 & 6 & 7 & 8 & 9 \\
\hline CF news & $\begin{array}{c}0.64 \\
(2.83)\end{array}$ & & & & $\begin{array}{c}0.96 \\
(2.90)\end{array}$ & $\begin{array}{c}0.51 \\
(2.88)\end{array}$ & $\begin{array}{c}0.99 \\
(2.98)\end{array}$ & $\begin{array}{c}0.59 \\
(3.48)\end{array}$ & $\begin{array}{c}0.92 \\
(4.18)\end{array}$ \\
\hline DR news & & $\begin{array}{l}-0.27 \\
(-2.26)\end{array}$ & & & $\begin{array}{l}-0.25 \\
(-1.78)\end{array}$ & $\begin{array}{l}-0.25 \\
(-1.76)\end{array}$ & $\begin{array}{c}-0.14 \\
(-1.27)\end{array}$ & $\begin{array}{l}-0.27 \\
(-1.77)\end{array}$ & $\begin{array}{c}-0.22 \\
(-1.53)\end{array}$ \\
\hline Mkt return & & & $\begin{array}{c}0.18 \\
(2.35)\end{array}$ & & $\begin{array}{c}0.18 \\
(2.79)\end{array}$ & & & $\begin{array}{c}0.13 \\
(2.25)\end{array}$ & $\begin{array}{c}0.12 \\
(2.21)\end{array}$ \\
\hline Sentiment & & & & $\begin{array}{l}0.0021 \\
(2.55)\end{array}$ & $\begin{array}{r}0.002 \\
(3.75)\end{array}$ & $\begin{array}{c}0.018 \\
(4.18)\end{array}$ & $\begin{array}{r}0.002 \\
(4.36)\end{array}$ & & \\
\hline CF news $x$ down mkt dummy & & & & & & $\begin{array}{c}0.95 \\
(2.47)\end{array}$ & & & \\
\hline DR news $\times$ down mkt dummy & & & & & & & $\begin{array}{c}-0.32 \\
(-1.58)\end{array}$ & & \\
\hline Down mkt dummy & & & & & & $\begin{array}{c}-0.08 \\
(-4.04)\end{array}$ & $\begin{array}{l}-0.06 \\
(-3.21)\end{array}$ & & \\
\hline CF news $\times$ pes. sent. dummy & & & & & & & & $\begin{array}{c}1.08 \\
(2.39)\end{array}$ & \\
\hline DR news $\times$ pes. sent. dummy & & & & & & & & & $\begin{array}{c}-0.76 \\
(-1.76)\end{array}$ \\
\hline Pes. sent. dummy & & & & & & & & $\begin{array}{l}-0.11 \\
(-4.40)\end{array}$ & $\begin{array}{c}-0.11 \\
(-4.17)\end{array}$ \\
\hline Adj. $R^{2}(\%)$ & 8.94 & 4.28 & 6.01 & 7.95 & 34.63 & 39.14 & 35.75 & 41.59 & 41.67 \\
\hline
\end{tabular}

story as the dominant factor of momentum profits. Cooper et al. (2004) find that higher momentum profits in up markets reverse in the long run. They also find that the initial statistically insignificant momentum profits following down markets reverse as well. Antoniou et al. (2013) find momentum profits following optimistic states reverse; however, they do not find any evidence for the reversals following pessimistic states.

Following the event-time methodology in Jegadeesh and Titman (2001), Lee and Swaminathan (2000), and Cooper et al. (2004), we plot the cumulative equal-weighted momentum returns for the 60 months skipping the month after the portfolio formation in Fig. 1. As described in Section 3.1, for each month $(t)$ in our sample period, we sort all NYSE and AMEX stocks into deciles based on their past six-month ( $t-6$ to $t-1)$ cumulative return, and identify the bottom (top) decile portfolio as the loser (winner) portfolio. We compute the equal weighted average monthly returns for the momentum portfolio WML, which is long in the winner portfolio and short in the loser portfolio for the following 60 months $(t+1$ to $t+60$ ) skipping a month $(t)$ after the formation period, forming time-series of raw returns corresponding to each event month $(t+1$ to $t+60$ ). We then compute the time-series means of these returns separately during up and down states (based on state of month t). ${ }^{16}$ Similar to the unconditional results in the above mentioned studies, we find that momentum profits reverse significantly following positive cash flow news. This is consistent with the overreaction theories of momentum. We also find significant reversals following negative cash flow news in states during which momentum is not significant. This finding is consistent with Cooper et al.'s (2004) finding of reversals in down markets and suggests that momentum is not the only driver of long-term reversals.
Since we document that momentum is statistically and economically strong in up-CF states even during the pessimistic states and down markets, it is worth examining the long run returns to the momentum portfolio to test the existence of any overreaction by "momentum traders" during these periods. We plot these long run returns in Fig. 2. This figure illustrates that momentum profits reverse in the long run following up-CF states even when past market returns are negative or investor sentiment is low. Collectively, these findings suggest that the declining risk-aversion of "momentum traders" in up-CF states plays a role in the overreaction to the news possibly at later stages of the momentum, which is consistent with the Hong and Stein (1999) model.

\subsection{Out-of-sample tests}

In this section, we examine the out-of-sample predictive power of aggregate cash flow news and discount rate news. We employ a VAR methodology with expanding windows and Jegadeesh and Titman (1993) calendar time momentum strategy to maintain a real time framework. For each month in the sample period, we rank stocks into deciles based on the cumulative returns over the past six-month ( $t-6$ to $t-1$, formation period). The top performing quintile is called the winner portfolio, and the worst performing one is called the loser portfolio.

These portfolios are held for the next 6 months $(t+1$ to $t+6$, holding period). We skip a month between formation and holding periods to avoid problems due to microstructure effects. Since new portfolios are formed in each month, we measure the return on a momentum portfolio in a given calendar month as the equal weighted average of six portfolios that remain open in that calendar month. For example, month $t+1$ momentum return (e.g., loser or winner quintile) is the equal-weighted average of the month $t+1$ returns of portfolios formed at months $t-6, t-5, t-4, t-3$, $t-2$ and $t-1$. This is equivalent to revising $1 / 6$ of the portfolio each month. This methodology produces a time-series of monthly 


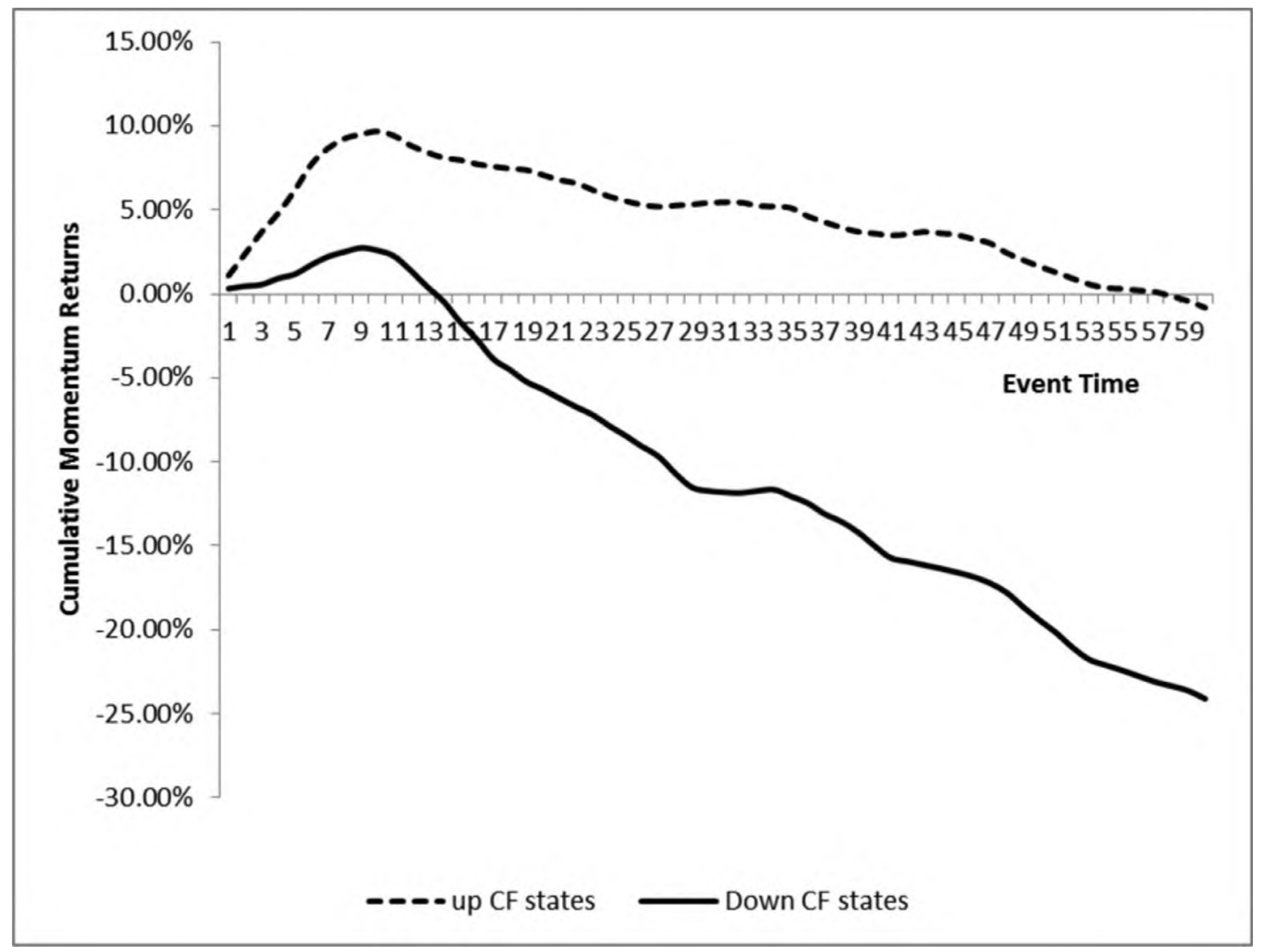

Fig. 1. Long- horizon momentum returns conditional on cash flow news.

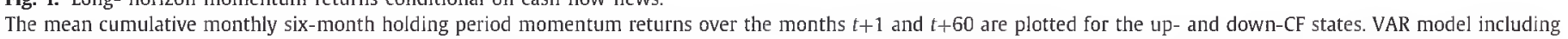

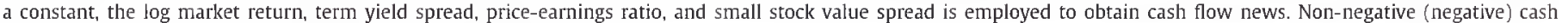
flow news over months $t-6$ to $t-1$ define up- (down) CF states.

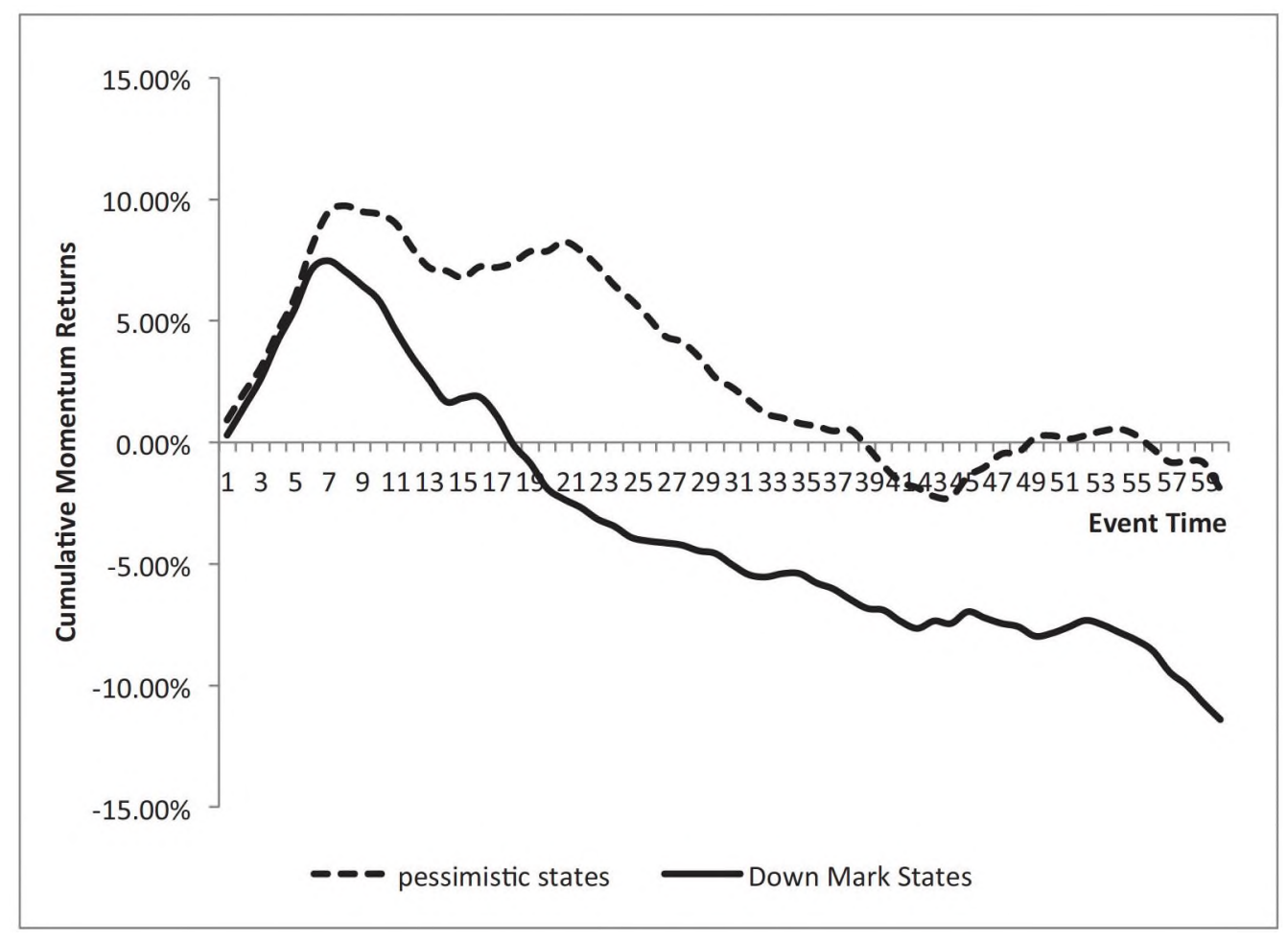

Fig. 2. Long- horizon momentum returns in UP-CF states during pessimistic and market decline periods.

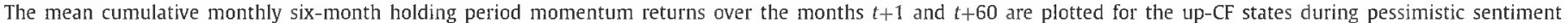

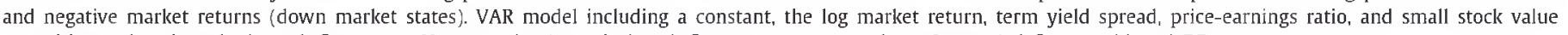
spread is employed to obtain cash flow news. Non-negative (negative) cash flow news over months $t-6$ to $t-1$ define up- (down) DR states. 


\section{Table 9}

Momentum returns conditional on cash flow and discount rate news-calendar time.

All NYSE and AMEX firms are sorted into deciles based on their lagged six-month returns from $t-6$ to $t-1$, skipping month $t$. Stocks priced less than $\$ 1$ at the end of

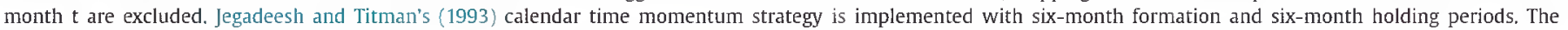

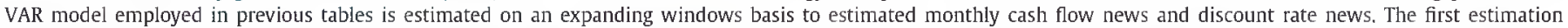

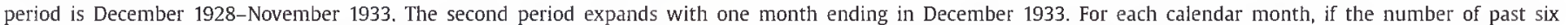

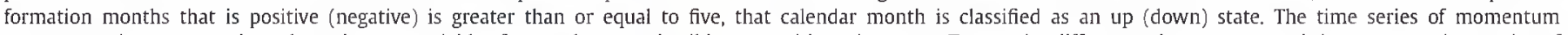
returns are then regressed on three dummy variables for up, down, and mild states without intercept. To test the differences between up and down states, time series of momentum returns are regressed on an intercept, mild and up dummy variables. The table presents the returns of losers, winners, and momentum returns and $t$-statistics for up, mild, and down states. The differences between up and down momentum returns and full sample returns and t-statistics are also reported.

\begin{tabular}{|c|c|c|c|c|c|c|c|c|c|}
\hline & \multicolumn{4}{|l|}{ CF states } & \multicolumn{4}{|c|}{ DR states } & \multirow[b]{2}{*}{ Full } \\
\hline & Up & Mild & Down & Up-down & Up & Mild & Down & Up-down & \\
\hline$N$ & 445 & 251 & 254 & & 342 & 193 & 415 & & 950 \\
\hline Loser & $\begin{array}{r}-0.20 \% \\
(-0.54)\end{array}$ & $\begin{array}{l}1.02 \% \\
(1.56)\end{array}$ & $\begin{array}{l}2.12 \% \\
(3.7)\end{array}$ & $\begin{array}{l}-2.32 \% \\
(-3.4)\end{array}$ & $\begin{array}{l}0.85 \% \\
(1.6)\end{array}$ & $\begin{array}{l}1.07 \% \\
(1.54)\end{array}$ & $\begin{array}{l}0.50 \% \\
(1.32)\end{array}$ & $\begin{array}{l}0.34 \% \\
(0.53)\end{array}$ & $\begin{array}{l}0.74 \% \\
(2.56)\end{array}$ \\
\hline Winner & $\begin{array}{l}1.11 \% \\
(3.3)\end{array}$ & $\begin{array}{l}1.91 \% \\
(4.64)\end{array}$ & $\begin{array}{l}2.43 \% \\
(5.68)\end{array}$ & $\begin{array}{l}-1.32 \% \\
(-2.43)\end{array}$ & $\begin{array}{l}1.57 \% \\
(4.79)\end{array}$ & $\begin{array}{l}1.69 \% \\
(3.11)\end{array}$ & $\begin{array}{l}1.74 \% \\
(4.95)\end{array}$ & $\begin{array}{l}-0.17 \% \\
(-0.36)\end{array}$ & $\begin{array}{l}1.67 \% \\
(7.49)\end{array}$ \\
\hline WML & $\begin{array}{l}1.31 \% \\
(6.67)\end{array}$ & $\begin{array}{l}0.88 \% \\
(1.89)\end{array}$ & $\begin{array}{l}0.31 \% \\
(0.85)\end{array}$ & $\begin{array}{l}1.00 \% \\
(2.41)\end{array}$ & $\begin{array}{l}0.72 \% \\
(2.25)\end{array}$ & $\begin{array}{l}0.63 \% \\
(1.57)\end{array}$ & $\begin{array}{l}1.24 \% \\
(4.7)\end{array}$ & $\begin{array}{l}-0.52 \% \\
(-1.24)\end{array}$ & $\begin{array}{l}0.93 \% \\
(5.1)\end{array}$ \\
\hline
\end{tabular}

momentum returns while avoiding biases in standard errors due to autocorrelation, which makes it possible to use conventional standard errors for evaluating the statistical significance of momentum returns.

In order to determine the cash flow news and discount rate news for each formation month, we estimate the VAR system with expanding windows. Our first window is from December 1928 to November 1933 covering 60 months. The next estimation window expands to include December 1933 covering 61 months. For each of these estimation windows, we calculate the cumulative cash flow news and discount rate news over the six months prior to the end of the windows. We then allocate calendar months during which we measure the momentum returns into up, mild, and down states. We first classify each of the past six formation months into up and down states based on whether there is positive and negative news, respectively. Then, we classify a calendar month as an up (down) state if at least five out of six formation periods have positive (negative) news. The remaining months are classified as mild states. We regress the time-series of momentum returns on three dummy variables for up, down, and mild states without intercept. In order to test for the differences between up and down states, we run time series regressions of momentum returns on an intercept, mild and up states dummy variables.

Table 9 presents the equal-weighted returns of losers, winners, and momentum returns along with their $t$-statistics. We find similar results to our event-time results presented earlier. The mean momentum return is $1.31 \%$ with a t-statistic of 6.67 . Momentum returns become weaker and statistically insignificant in mild and down states, respectively. Up-CF states predict both statistically and economically significantly higher momentum returns than down- $\mathrm{CF}$ states. The difference in momentum returns between up- and down-CF states is a monthly $1.00 \%$ with a t-statistic of 2.41. Conversely, the out-of-sample predictability tests suggest that discount rate news has no power for forecasting momentum returns. The difference between up- and down-DR states is $0.52 \%$ with a $t$-statistic of 1.24 . Overall, these out-of-sample predictability tests confirm the earlier findings that cash flow news is more important than discount rate news in predicting momentum portfolio returns. ${ }^{17}$

\section{Conclusion}

In this paper, we examine the relation between cash flow news, discount rate news and momentum in stock prices. We follow Campbell and Vuolteenaho (2004) to decompose past unexpected market returns into components related to cash flow news and discount rate news, and find that cash flow news dominates discount rate news in forecasting price momentum. Previous literature such as Cooper et al. (2004) and Antoniou et al. (2013) find that price momentum exists only when past market returns are positive or investor sentiment is optimistic. We contribute to this literature by showing that price momentum is both statistically and economically significant if past market-wide cash flow news is positive even in cases where past market return is negative or sentiment is pessimistic. Our finding, that the higher momentum profits in positive cash flow news periods is primarily driven by the continued underperformance of losers, is consistent with the behavioral explanation of price momentum provided by Hong and Stein (1999) in the sense that investor underreaction to the contradictory news will be more pronounced when changes in wealth are relatively more permanent.

\section{References}

Antoniou, C., Doukas, A.J., Subrahmanyam, A., 2013. Cognitive dissonance, sentiment and momentum. Journal of Financial and Quantitative Analysis 48, 245-275.

Arena, P.M., Haggard, K.S., Yan, X., 2008. Price momentum and idiosyncratic volatility. The Financial Review 43, 159-190.

Asness, C., 1997. The interaction of value and momentum strategies. Financial Analyst Journal $53,29-36$

Baker, M., Wurgler, J., 2000. The equity share in new issues and aggregate stock returns. Journal of Finance 55, 2219-2257.

Barberis, N., Shleifer, A., Vishny, R., 1998. A model of investor sentiment. Journal of Financial Economics 49, 307-343.

Berk, J., Green, R., Naik, V., 1999. Optimal investment, growth options, and security returns. Journal of Finance 60, 1639-1672.

Campbell, J.Y., Ammer, J., 1993. What moves the stock and bond markets? A variance decomposition for long-term asset returns. Journal of Finance $48(1), 3-37$.

Campbell, J.Y., Shiller, R.J., 1988. The dividend-price ratio and expectations of future dividends and discount factors. Review of Financial Studies 1 (3), 195-228.

Campbell, J.Y., 1991. A variance decomposition for stock returns. Economic Journal 101, 157-179.

Campbell, J.Y., Vuolteenaho, T., 2004. Bad beta, good beta. American Economic Review 94, 1249-1275.

Campbell, J.Y., Giglio, S., Polk, C., 2013. Hard times. Review of Asset Pricing Studies 3, 95-132.

Chen, L., Zhao, X., 2009. Return decomposition. Review of Financial Studies 22, 5213-5249.

Chordia, T., Shivakumar, L., 2002. Momentum, business cycle, and time-varying expected return. Journal of Finance 57, 985-1019.

Chui, A., Titman, S., Wei, K.C.J., 2000. Momentum, Ownership Structure, and Financial Crises: An Analysis of Asian Stock Markets. University of Texas at Austin Working paper. 
Cohen, R.B., Gompers, PA., Vuolteenaho, T., 2002. Who underreacts to cash-flow news? Evidence from trading between individuals and institutions. Journal of financial Economics 66 (2), 409-462.

Cooper, J.M., Gutierrez Jr, R.C., Hameed, A., 2004. Market states and momentum. Journal of Finance 59, 1345-1365.

Daniel, K., Hirsleifer, D., Subrahmanyam, A., 1998. Investor psychology and security market under- and overreactions. Journal of Finance 53, 1839-1885.

Daniel, K., Titman, S., 1999. Market efficiency in an irrational world. Financial Analyst Journal $55,28-40$.

Daniel, K., Grinblatt, M., Titman, S., Wermers, R, 1997. Measuring mutual fund performance with characteristic-based benchmarks. Journal of Finance 52 , 1035-1058.

Eisdorfer, A., 2007. The importance of cash-flow news for financially distressed firms. Financial Management 36, 33-48.

Fama, E.F., French, K.R., 1993. Common risk factors in the returns on stocks and bonds. Journal of Financial Economics 33, 3-56.

Hong, H., Stein, J., 1999. A unified theory of underreaction, momentum trading, and overreaction in asset markets. Journal of Finance 54, 2143-2184

Hong, H., Stein, J.C., 2007. Disagreement and the Stock Market. Journal of Economic Perspectives 21 (2), 109-128.

Hong, H., Lim, T., Stein, J.C., 2000. Bad news travels slowly: size, analyst coverage and the profitability of momentum strategies. Journal of Finance 55, 265-295.

Jegadeesh, N., Titman, S. 1993. Returns to buying winners and selling losers: implications for stock market efficiency. Journal of Finance $48,65-91$.
Jegadeesh, N., Titman, S., 2001. Profitability of momentum strategies: an evaluation of alternative explanations. Journal of Finance 56, 699-720.

Johnson, T.C. 2002. Rational momentum effects. Journal of Finance 57, 585-608.

Kim, D., Roh, T., Min, B., Byun, S., 2014. Time-varying expected momentum profits. Journal of Banking and Finance 49, 191-215.

Lee, Charles M.C., Swaminathan, B., 2000. Price momentum and trading volume. Journal of Finance 55, 2017-2069.

Lewellen, J., 1999. The time-series relations among expected return, risk, and bookto-market. Journal of Financial Economics 54 (1), 5-43.

Liu, L.X. Zhang, L., 2008. Momentum profits, factor pricing, and macroeconomic risk. Review of Financial Studies 21, 2417-2448.

Nyberg, P., Poyry, S., 2014. Firm expansion and stock price momentum. Review of Finance 15, 1465-1505

Pontiff, J., Schall, L.D., 1998. Book-to-market ratios as predictors of market returns. Journal of Financial Economics 49, 141-160.

Rouwenhorst, G., 1998. International momentum portfolios. Journal of Finance 53, $267-284$.

Sagi, J.S., Seasholes, M.S., 2007. Firm-specific attributes and the cross-section of momentum. Journal of Financial Economics 84, 389-434.

Schiller, R., 2000. Irrational Exuberance. Princeton University Press.

Verardo, M., 2009. Heterogeneous beliefs and momentum. Journal of Financial and Quantitative Analysis 44, 795-822. 